\title{
Differential gene expression in abdomens of the malaria vector mosquito, Anopheles gambiae, after sugar feeding, blood feeding and Plasmodium berghei infection
}

\author{
Ali N Dana ${ }^{1}$, Maureen E Hillenmeyer, Neil F Lobo ${ }^{1}$, Marcia K Kern ${ }^{1}$, \\ Patricia A Romans ${ }^{2}$ and Frank H Collins*1
}

Address: ${ }^{1}$ Center for Tropical Disease Research and Training, Department of Biological Sciences, University of Notre Dame, Notre Dame, IN 46556 , USA and ${ }^{2}$ Department of Zoology, University of Toronto, Toronto, ON M5S 3G5, Canada

Email: Ali N Dana - adana@iupui.edu; Maureen E Hillenmeyer - maureenh@stanford.edu; Neil F Lobo - nlobo@nd.edu; Marcia K Kern - mkern@nd.edu; Patricia A Romans - victorie@zoo.utoronto.ca; Frank H Collins* - frank@nd.edu

* Corresponding author

Published: 19 May 2006

BMC Genomics 2006, 7:119 doi:10.1186/1471-2164-7-119

This article is available from: http://www.biomedcentral.com//47/-2164/7/II9

(C) 2006 Dana et al; licensee BioMed Central Ltd.

This is an Open Access article distributed under the terms of the Creative Commons Attribution License (http://creativecommons.org/licenses/by/2.0), which permits unrestricted use, distribution, and reproduction in any medium, provided the original work is properly cited.
Received: 17 October 2005

Accepted: 19 May 2006

\begin{abstract}
Background: Large scale sequencing of cDNA libraries can provide profiles of genes expressed in an organism under defined biological and environmental circumstances. We have analyzed sequences of 454I Expressed Sequence Tags (ESTs) from 3 different cDNA libraries created from abdomens from Plasmodium infection-susceptible adult female Anopheles gambiae. These libraries were made from sugar fed (S), rat blood fed (RB), and $P$. berghei-infected (IRB) mosquitoes at 30 hours after the blood meal, when most parasites would be transforming ookinetes or very early oocysts.

Results: The S, RB and IRB libraries contained I727, I I 45 and I 669 high quality ESTs, respectively, averaging 455 nucleotides (nt) in length. They assembled into 1975 consensus sequences - 567 contigs and 1408 singletons. Functional annotation was performed to annotate probable molecular functions of the gene products and the biological processes in which they function. Genes represented at high frequency in one or more of the libraries were subjected to digital Northern analysis and results on expression of 5 verified by qRT-PCR.

Conclusion: I $3 \%$ of the 1965 ESTs showing identity to the A. gambiae genome sequence represent novel genes. These, together with untranslated regions (UTR) present on many of the ESTs, will inform further genome annotation. We have identified 23 genes encoding products likely to be involved in regulating the cellular oxidative environment and 25 insect immunity genes. We also identified 25 genes as being up or down regulated following blood feeding and/or feeding with $P$. berghei infected blood relative to their expression levels in sugar fed females.
\end{abstract}

\section{Background}

Sequencing of the Anopheles gambiae genome was completed in 2002 [1]. Annotation and gene prediction have been ongoing. Although more than 14,700 genes and more than 16,100 transcripts have now been predicted, the functions of approximately $40 \%$ of the gene products remain unknown and in silico annotations of many others still require verification $[1,2]$. Information about the 
Table I: cDNA LIBRARY INSERT AND EST SIZES*

\begin{tabular}{|c|c|c|c|c|c|}
\hline $\begin{array}{l}\text { Clone Source } \\
\text { Library }\end{array}$ & $\mathbf{N}$ & Mean length (bp) & \pm SE & Max. (bp) & Min. (bp) \\
\hline $\mathbf{S}$ & 243 & 1003 & 33 & 3526 & 322 \\
\hline $\mathbf{R B}$ & 189 & 1156 & 45 & 3738 & 152 \\
\hline IRB & 272 & 1044 & 28 & 2789 & 317 \\
\hline Average & & 1068 & 35 & 3351 & 264 \\
\hline EST Source & $\mathbf{N}$ & $\begin{array}{c}\text { Mean EST length } \\
(\mathbf{n t})^{\dagger}\end{array}$ & \pm SE & Max. (nt) & Min. (nt) \\
\hline S singletons & 590 & 404 & 8 & 820 & 100 \\
\hline $\mathrm{RB}$ singletons & 381 & 394 & 8 & 748 & 100 \\
\hline IRB singletons & 437 & 377 & 8 & 785 & 100 \\
\hline Contigs & 567 & 595 & 11 & 1585 & 104 \\
\hline Average & & 455 & 9 & 1039 & 101 \\
\hline
\end{tabular}

*Library abbreviations are defined in the text. $\mathrm{N}=$ number of clone inserts, ESTs sequenced TThe mean EST length in nucleotides (nt) is the length following end-trimming, short sequence filtering and EST contig assembly.

$\mathrm{SE}=$ standard error of the mean.

structure, annotation and expression of these genes is necessary for understanding how they are regulated spatially and temporally, and for determining how they function in the mosquito. Large-scale sequencing of cDNA libraries, captures expressed gene products, creating a "molecular snapshot" of the transcriptome. A single sequence read corresponds to the transcript from which it was derived and generates an EST for the underlying gene. Genes can be identified putatively by comparing the derived ESTs with sequences of known annotated genes and gene products.

Large-scale EST sequencing of different cDNA populations provide opportunities for exploration of gene expression under defined biological and environmental conditions. All cells are complex molecular environments regulated by the information in their genes encoding thousands of proteins involved in a multitude of processes. However, only a subset of these genes is actively transcribed at any one time, and in eukaryotes, in any one organ, tissue and cell type. The "digital Northern", an in silico form of transcript profiling, can be used to study gene expression by comparing ESTs from clones randomly picked from two or more cDNA libraries created from non-normalized mRNA populations [3-5]. The frequency of any specific sequence should reflect the relative expression level or abundance of that transcript in the libraries [6]. Genes are identified as being differentially expressed using a number of statistical methods $[4,7,8]$. Finally, the ontology of a gene, the molecular function and biological process in which its product is involved, provide information about the system in which it is expressed.
Infection of the adult female anopheline mosquito with malaria parasites elicits both local and systemic responses from a range of vector organs and tissues. Plasmodium infection is also coincident with the ingestion of a blood meal which sets in motion a complex sets of events including digestion and egg production [9-11]. These events involve extensive changes in gene expression in multiple organs, three of which are found in the abdomen, midgut, fat body and ovaries [12-16]. Normal patterns of gene expression in these organs are often significantly further altered in parasitized mosquitoes $[1,17,18]$.

We have investigated genes that are up and down regulated following blood feeding and Plasmodium berghei infection of A. gambiae females using a direct sequencing approach. Three cDNA libraries were created from the abdomens of sugar-fed, naïve blood-fed, and $P$. bergheiinfected females. These whole abdomens contain a multitude of organs, tissues and cell types, and provide an inventory of genes expressed during blood digestion, vitellogenesis and Plasmodium infection. ESTs were obtained and their frequencies compared among the 3 libraries to create transcript profiles. EST annotation using existing databases, BLAST tools and gene ontology classifications yielded information on the most dramatic transcriptional responses of these mosquitoes to blood feeding and parasitism. This catalog of abdominal gene expression will contribute to a more global understanding of anopheline physiology and immunity. It will also provide a resource for improving annotation of the A. gambiae genome, thus making it more useful for vector biologists 
A

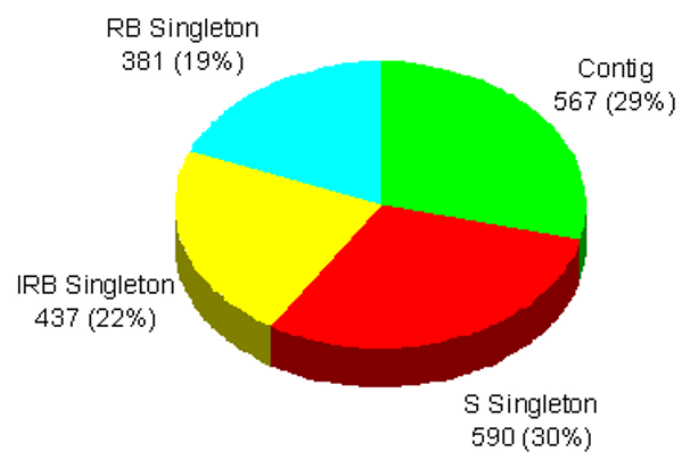

B

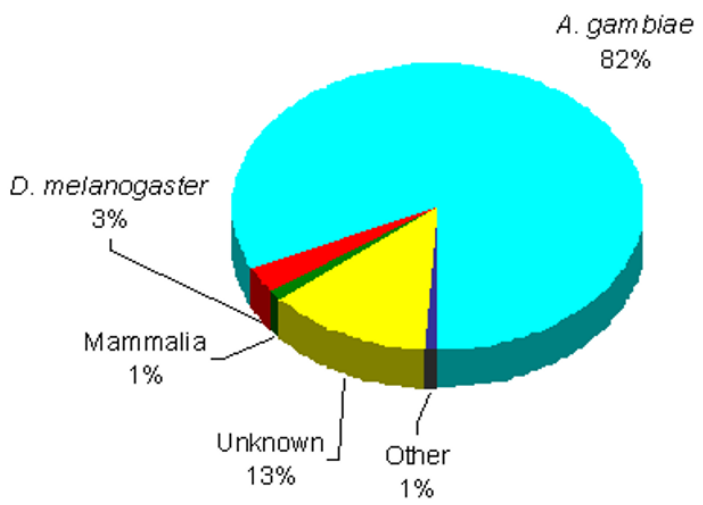

C

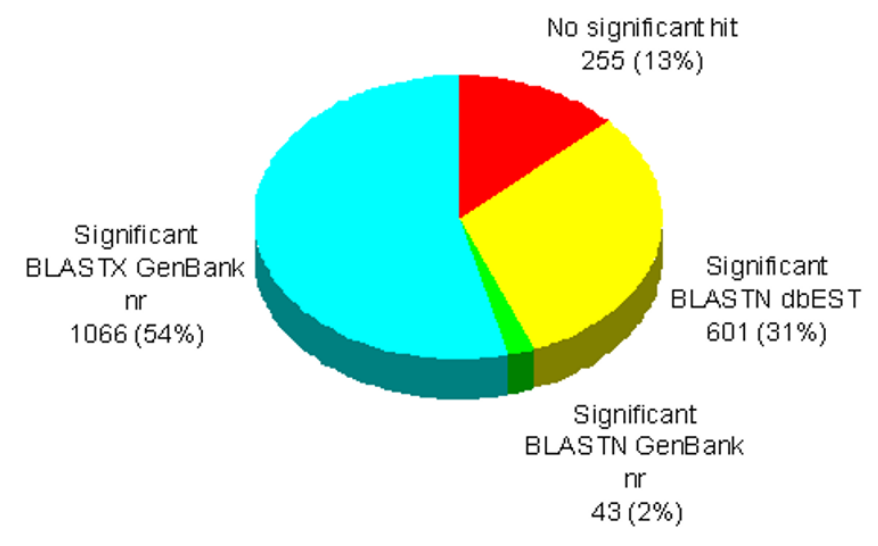

\section{Figure I}

Distributions of ESTs among the S, RB and IRB libraries. A total of I408 singletons, unique transcripts, and 567 multi-EST contigs was examined. A. Distribution of singletons among libraries relative to total contigs. The \% of 1975 singletons and contigs is shown in brackets following the number of singletons within each library. B. Taxonomic distribution of all 1975 assembled sequence homologies following BLASTX and BLASTN searches of GenBank nr and a BLASTN search of dbEST. C. Identification of 1965 transcripts sharing $A$. gambiae genomic identity, $\mathrm{E}<10^{-4}$. 
and scientists studying homologous genes in other organisms. Most importantly, increased understanding of anopheline biology at the molecular level may open new avenues for intervention against malaria transmission.

\section{Results and discussion}

Three unidirectionally cloned cDNA libraries were constructed from mRNA isolated from abdomens of A. gambiae females that had been fed on $20 \%$ sucrose (S library), on rat blood (RB), or on rat blood infected with $P$. berghei (IRB), and then maintained at $19-20^{\circ} \mathrm{C}$ for $30 \mathrm{~h}$. To determine the staging of $P$. berghei infections in the susceptible 4arr strain, we chose to count melanized transforming ookinetes and early oocysts in the L-35 refractory strain using the rationale that transforming ookinetes/ early oocysts are the infection stages being examined in this study whereas counts of later stage oocysts at 5 or $6 \mathrm{~d}$ post infection would be likely to underestimate infection intensity at the experimental times points. We acknowledge that this approach assumes that the L35 and 4arr strains experience similar infection time kinetics and similar invasion rates of the midgut by ookinetes, infection attributes that have not been formally established. At $30 \mathrm{~h}$ post infection (PI), the majority of parasites in infected L35 strain mosquitoes were ookinetes still traversing the midgut or transforming to early oocysts on the basal surface of the midgut: the mean number of parasites per $A$. gambiae midgut at $30 \mathrm{~h} \mathrm{PBM}$ was $10 \pm 11$ (standard error of the mean, SEM), rising to a peak of $24 \pm 23$ by $36 \mathrm{~h}$ PBM. A post hoc Tukey test showed a significant difference in oocyst numbers between these time points, $\mathrm{P}<0.05$. These values for A. gambiae infection by $P$. berghei were similar to infection intensities published elsewhere $[19,20]$. The unamplified S, RB and IRB libraries contained a total of $3.09 \times 10^{6}, 1.22 \times 10^{7}$, and $1.13 \times 10^{6} \mathrm{pfu} /$ $\mathrm{ml}$, respectively. The average insert size of 704 clones randomly picked from all three libraries was calculated to be $1068 \pm 35$ bp (Table 1$)$.

cDNA inserts from 3264, 1920, and 3456 white plaques randomly picked from the $\mathrm{S}, \mathrm{RB}$, and IRB libraries, respectively, were amplified by PCR and sequenced from their 5' ends. The resulting ESTs were filtered based on sequence trace file quality, screened for mitochondrial contamination and assembled into contigs using SeqMan II. Following the initial SeqMan assembly, only high quality nonmitochondrial sequences $>100 \mathrm{bp}$, corresponding to 1736,1216 , and 1772 ESTs from each of the S, RB and IRB libraries, respectively, were analyzed further. Their average length was $455 \pm 8$ nt (Table 1 ). These 4724 high quality ESTs assembled into a total of 1989 contigs and singletons. Sequence identity searches showed that 4 contigs and 10 singletons were of non-mosquito origin: these sequences shared no identity with the A. gambiae genome [21] but did with proteins such as rat alpha and beta hemoglobin chains. When these contaminants had been removed, a total of 4541 high quality ESTs remained for further analysis, 1727 from S, 1145 from RB, and 1669 from IRB. They assembled into 1975 consensus sequences, 567 contigs and 1408 singletons (Table 1, Figure $1 \mathrm{~A})$. Each was given a unique assembled sequence (AS) number. These EST sequences can be accessed through the NCBI EST database, dbEST [22].

The EST assembly may have estimated the number of unique genes in the libraries inaccurately due to sequencing errors, sequence polymorphisms, alternate splicing of transcripts, and lack of overlap of 3 'and 5 ' sequences representing the same gene product $[22,23]$. To evaluate this inaccuracy, we compared sequences sharing the same top BLAST hit by aligning them with the nucleotide sequences of their predicted genes using CLUSTAL W [24,25] and its default parameters. Of the 974 assembled sequences that shared identity with predicted A. gambiae proteins, 65 aligned with a protein already represented in the data set. When assembled sequences identified as being from the same gene failed to align, they failed to do so mainly because their sequences did not overlap, i.e., they were from different parts of a gene. Alternative splicing of transcripts and sequence dissimilarity in excess of contig assembly thresholds also contributed to these alignment failures. We estimate that the total number of assembled sequences may have overestimated the total number of unique genes by approximately $4 \%$.

\section{Sequence identity searches}

The 1975 assembled A. gambiae EST contig and singleton sequences were distributed among the three libraries as shown in Figure 1A. They were searched against nucleotide and protein databases for identity to known genes and proteins using BLAST algorithms. $82 \%$ of them showed highest identity to predicted or identified A. gambiae genes, $3 \%$ to Drosophila melanogaster genes, $1 \%$ to mammalian genes, $1 \%$ to other taxonomic groups, while $13 \%$ remained unknown after this analysis (Figure $1 \mathrm{~B}$ ) BLASTN alignments identified 1965 consensus sequences with significant identity $\left(<\mathrm{E}^{-4}\right)$ to the A. gambiae genome assembly and 10 that did not (Figure 1C). The 1965 consensus sequences identified as being derived from A. gambiae are composed of 1710 sequences which shared identity with publicly available nucleotide and/or amino acid sequences from other organisms and 255 sequences which showed no identity to any sequence in the GenBank nr and dbEST databases. 95\% (1620/1710) of the A. gambiae-derived consensus sequences exhibited identity with A. gambiae protein sequences predicted in silico from the genome sequence and sequences submitted to databases prior to genome sequencing (data not shown). These included 974 sequences with identity to predicted proteins, 48 with identity to protein sequences derived 
from other submitted gene sequences, and 598 with identity to ESTs. It is surprising that no Plasmodium ESTs were identified.

Only 49.6\% (974/1965) of assembled sequences sharing identity with the A. gambiae genome also shared identity with predicted A. gambiae proteins. The remaining 991 sequences may be derived from $5^{\prime}$ or $3^{\prime}$ untranslated regions (UTRs), may lack an ORF due to frame shift errors occurring during cloning or sequencing, may be 5 ' truncated, or may be just too short to be identified, despite the $100 \mathrm{nt}$ cutoff. They may also represent novel genes. Holt et al. [1] concluded that more than 1300 genes might have escaped prediction in the first annotation of the A. gambiae genome. The current gene number prediction is 14,707 [2], an increase of more than 1000 from the original estimate. Computational techniques may inaccurately predict genes by missing exons derived solely from promoters, or that are due to alternative splicing of transcripts or to use of non-canonical splice sites, alternative translational initiation and/or polyadenylation sites [26]. Thus, the majority of ESTs generated in this study may enhance gene prediction in the A. gambiae genome through refinement of existing gene models and providing evidence for new ones.

By definition, ESTs are generally short sequences of approximately 300-500 nt derived from transcripts [27]. The sequences assembled in this study had an average length of $455 \mathrm{nt}$ and many could have consisted mainly of 5'- or 3'-UTRs. The average lengths of the 5'- and 3'-UTRs in Release 3 of the Drosophila genome were 265 and 442 nt respectively, and the average ratio of their length/coding sequence was 0.75 [28]. Accordingly, BLASTN sequence identity searches were performed against dbEST to annotate assembled sequences that might have lacked a predicted ORF because they consisted mainly of either a long 5'-UTR, or of 3 '-UTR resulting from 5 ' truncation of transcripts during cDNA library construction. dbEST contains more than 100,000 A. gambiae ESTs, the majority of which were generated from large-scale sequencing of two non-normalized cDNA libraries constructed from non blood-fed and blood-fed whole adult females [1]. 601, or $66.9 \%$ of the 898 unique gene products sharing identity with the genome but not identified by BLASTX search of GenBank Nr were identified by this BLASTN search of dbEST. $99.5 \%$ of these shared sequence identity with at least one A. gambiae EST. After completion of all identity searches, 255 assembled sequences still failed to show significant identity with the ESTs in dbEST or with the predicted proteins in GenBank Nr, though they did with the A. gambiae genome. These appear to be truly novel.

Since $a b$ initio gene prediction programs used to analyze genomes can only identify open reading frames (ORFs),
cDNA sequences provide an essential tool for properly validating gene identification and annotation. Misra et al. [28] reported that reannotation of the Drosophila genome following Release 3 resulted in much-improved prediction of alternatively spliced transcripts and annotation of UTRs due to the increased number of ESTs and cDNAs available. The reannotation resulted in changes to $85 \%$ of gene models, including major changes in $40 \%$ of predicted proteins, without significantly affecting the number of genes predicted. Since the untranslated regions of transcripts contain sequences influencing transcript fates including subcellular localization and mRNA turnover, as well as cis-regulatory information, a database of nucleotide sequences corresponding to predicted transcripts that includes UTRs may provide a better tool for EST and genome annotation than a database of predicted proteins. Most importantly, however, accurate identification of UTRs and alternative patterns of intron splicing in the A. gambiae genomic sequence that can be obtained through EST projects such as this one are necessary for ultimately understanding gene regulation at the post-transcriptional level.

\section{Functional annotation of ESTs}

The adult female mosquito abdomen contains several complex organs and tissues including the midgut, the ovaries and the fat body. These function in the normal processes of blood meal digestion and egg production, as well as in responses to infection by and defense against pathogens. Functional annotation of the abdominal genes represented in the three cDNA libraries was performed to gain insight into the physiological events required for reproduction and the pathological ones induced by infection with Plasmodium. Molecular function and biological process were assigned to the consensus sequences based on sequence similarity to known genes and proteins and to the existing gene indices for A. gambiae and D. melanogaster, TIGR Gene Index and GadFly, respectively.

The 1975 gene products predicted after EST clustering were categorized into 8 major biological processes with 34 subdivisions. A $9^{\text {th }}$ category, Unknown, represents gene products with no ascribable function. The library-specific results of these functional assignments are in Table 2. More detailed annotation of all 1975 gene products are provided [see Additional file 1]. For all three libraries taken together, the largest category, representing 1329 gene products or $67.3 \%$ of the total, remains the "Unknown". The three next most numerous categories are "Metabolism", 441 unique transcripts, 23.3\% of the total; "Protein Synthesis", 418, 21.2\%; and "Egg Production", $81,4.1 \%$. The largest represented subdivision is "Translation". Perhaps unexpectedly, the genes likely to be involved in egg production are represented in similar proportions among the three libraries. While it is possible 
Table 2: BIOLOGICAL PROCESSES OF GENES REPRESENTED IN LIBRARIES*

\begin{tabular}{|c|c|c|c|}
\hline & Total S & Total RB & Total IRB \\
\hline \multicolumn{4}{|l|}{ Metabolism } \\
\hline $\begin{array}{l}\text { Simple/Complex Carbohydrate } \\
\text { Metabolism and Transport }\end{array}$ & $21(28) \dagger$ & $15(17)$ & $13(15)$ \\
\hline Oxidative Phosphorylation & $4 \mid(64)$ & $38(61)$ & $30(69)$ \\
\hline Lysosomal Enzymatic Digestion & I (2) & 0 & $4(4)$ \\
\hline Protein Digestion & $13(63)$ & $7(49)$ & $11(63)$ \\
\hline $\begin{array}{l}\text { Protein Modification, Metabolism, } \\
\text { Transport and Localization }\end{array}$ & $42(54)$ & $38(49)$ & $39(63)$ \\
\hline $\begin{array}{l}\text { Amino Acid and Derivative } \\
\text { Metabolism and Transport }\end{array}$ & $10(13)$ & $6(10)$ & $16(20)$ \\
\hline $\begin{array}{l}\text { Nucleobase/Nucleoside/ } \\
\text { Nucleotide/Nucleic acid } \\
\text { Metabolism and Transport }\end{array}$ & $9(21)$ & $10(12)$ & $13(19)$ \\
\hline $\begin{array}{l}\text { Fatty Acid/Lipid Metabolism and } \\
\text { Transport }\end{array}$ & $9(11)$ & $8(8)$ & $5(6)$ \\
\hline $\begin{array}{l}\text { Vitamin/Vitamin Derivative/ } \\
\text { Cofactor Metabolism and } \\
\text { Transport }\end{array}$ & $2(3)$ & $2(3)$ & $2(2)$ \\
\hline $\begin{array}{l}\text { Xenobiotic Metabolism and } \\
\text { Transport }\end{array}$ & $5(5)$ & $7(8)$ & $5(6)$ \\
\hline Pigment Synthesis and Transport & $\mathrm{I}(\mathrm{I})$ & $2(2)$ & $4(5)$ \\
\hline Other & $3(4)$ & $6(6)$ & $3(3)$ \\
\hline Total & 157 (269) & $139(225)$ & $145(275)$ \\
\hline \multicolumn{4}{|l|}{ Transport } \\
\hline Ion Transport & $10(11)$ & $14(16)$ & $12(14)$ \\
\hline Receptor-mediated Endocytosis & $7(10)$ & $4(4)$ & $6(11)$ \\
\hline Total & $17(21)$ & $18(20)$ & $18(25)$ \\
\hline \multicolumn{4}{|l|}{ Protein Synthesis } \\
\hline Transcription and mRNA & $17(23)$ & $19(20)$ & $19(21)$ \\
\hline \multicolumn{4}{|l|}{ Processing } \\
\hline Translation & $108(436)$ & $97(325)$ & II 5 (482) \\
\hline Protein Folding & $14(24)$ & $19(21)$ & $10(13)$ \\
\hline Total & $139(483)$ & $135(366)$ & $144(5 \mid 6)$ \\
\hline \multicolumn{4}{|l|}{ Cellular Processes } \\
\hline Cell Cycle & $14(17)$ & $10(13)$ & $6(11)$ \\
\hline Cellular Proliferation & $4(4)$ & $2(2)$ & $3(3)$ \\
\hline Chromatin Assembly/Disassembly & $4(6)$ & $5(7)$ & $5(10)$ \\
\hline Apoptosis & $2(2)$ & $2(2)$ & $5(7)$ \\
\hline Senescence & $2(3)$ & 0 & I (2) \\
\hline Viral Life Cycle & $\mathrm{I}(\mathrm{I})$ & $\mathrm{I}(\mathrm{I})$ & 0 \\
\hline Total & $27(33)$ & $20(25)$ & $20(33)$ \\
\hline \multicolumn{4}{|l|}{ Egg Production } \\
\hline $\begin{array}{l}\text { Vitellogenesis/Oogenesis/ } \\
\text { Embryogenesis }\end{array}$ & $29(33)$ & $24(40)$ & $27(60)$ \\
\hline Melanization & 0 & $I(1)$ & 0 \\
\hline Total & $29(33)$ & $25(4 I)$ & $27(60)$ \\
\hline
\end{tabular}


Table 2: BIOLOGICAL PROCESSES OF GENES REPRESENTED IN LIBRARIES* (Continued)

\begin{tabular}{|c|c|c|c|}
\hline \multicolumn{4}{|l|}{ Cellular Communication } \\
\hline Signal Transduction & II (14) & $5(7)$ & $6(12)$ \\
\hline Cell-cell Signaling & $4(7)$ & $4(4)$ & $2(3)$ \\
\hline Total & $15(21)$ & $9(11)$ & $8(15)$ \\
\hline \multicolumn{4}{|l|}{$\begin{array}{l}\text { Intra-/Extra-cellular Architecture } \\
\text { Maintenance }\end{array}$} \\
\hline Structural & $8(35)$ & II (24) & $6(30)$ \\
\hline Muscle-related & $6(6)$ & $4(5)$ & $7(8)$ \\
\hline Cell Adhesion & $3(3)$ & $3(3)$ & $1(1)$ \\
\hline $\begin{array}{l}\text { Cytoskeleton Organization and } \\
\text { Biogenesis }\end{array}$ & $4(6)$ & $12(17)$ & $12(18)$ \\
\hline Total & $21(50)$ & $30(49)$ & $26(57)$ \\
\hline \multicolumn{4}{|l|}{$\begin{array}{l}\text { Response to Stress/External } \\
\text { Stimulus }\end{array}$} \\
\hline Response to Oxidative Stress & $7(9)$ & $8(11)$ & $14(29)$ \\
\hline Immune/Defense Response & II (29) & $9(15)$ & $14(20)$ \\
\hline Chemosensory Perception & $3(3)$ & $1(1)$ & $1(1)$ \\
\hline Total & $2 I(4 I)$ & $18(27)$ & $29(50)$ \\
\hline \multicolumn{4}{|l|}{ Unknown } \\
\hline Total & $573(776)$ & $326(415)$ & $430(663)$ \\
\hline
\end{tabular}

*This analysis does not take into account that some genes are represented in more than I library or that more than one biological process may have been ascribed to particular genes.

†Number of Contigs containing one or more ESTs (total ESTs/genes).

that this result is an artifact created by timing the mRNA samples used for library creation to $30 \mathrm{hr} P B M$ at $19^{\circ} \mathrm{C}$, a time close to the peak of vitellogenic activity at this temperature, the gene products involved in oogenesis may also play other roles in the life cycle of the mosquito. For instance, some of the gene products in the Toll pathway, a signaling cascade that controls dorsal-ventral patterning of the Drosophila embryo during development [29], are also important in the induction of several immunerelated peptides [30-33].

The first large scale studies to identify genes involved in mosquito responses to Plasmodium infection relied on cDNA libraries prepared from bacteria-challenged mosquito tissues [34,35]. Three more recent studies have reported direct screens for Anopheles genes responding to Plasmodium infection [17,36,37]. Our IRB library has provided an additional opportunity to study transcripts whose abundance may be regulated by infection with $P$. berghei. It showed an increase in the proportion of gene products present in biological processes likely to be responses to parasite infection, including responses to oxidative stress and immunity-related defenses. Some transcript profiles looked at here are based on the comparison of ESTs that vary by only one unit. Though this may be considered to be of limiting value, it is important to note that most profiles are consistent with previous stud- ies and are discussed individually. In addition, the tissues used here are composed of whole abdomens, which contain gut, blood cells, fat body, epidermis, ovaries and other cell and tissue types. Differences of gene expression patterns between this and previous studies may relate to the somewhat different tissues that were assayed.

Reactive oxygen species may be generated through the activities of nitric oxide synthase (NOS) and peroxidases $[38,39]$. Transcripts encoding number of enzymes involved in regulating the cellular oxidative environment were identified in all three libraries. These include multiple glutathione S-transferases (GSTs), peroxidases, and peroxiredoxin (Table 3), but not nitric oxide synthase (NOS). Failure to identify inducible NOS transcripts at least in the IRB library may relate to the abundance and or timing of its transcription though $P$. berghei invasion induced NOS both systemically and locally in the midgut in Anopheles stephensi 24-48 hours post infection (PI) [40]. In parasite-damaged midgut cells, the increase in NOS levels was concurrent with other morphological changes associated with apoptosis [41]. NOS is known to be activated transcriptionally in A. gambiae within 22-24 hr PI with $P$. berghei $[42,43]$. Activation is mainly in the midgut, as expected for this time period. 
Table 3: OXIDATION AND STRESS RESPONSE GENES

\begin{tabular}{|c|c|c|c|c|c|c|c|c|c|c|c|c|c|}
\hline AS & \# S ESTs & $\begin{array}{l}\text { \#RB } \\
\text { ESTs }\end{array}$ & $\begin{array}{l}\text { \# IRB } \\
\text { ESTs }\end{array}$ & Total \# ESTs & Genome Scaffold & Start & End & E value & Blast Type & Accession & Blast Hit & E value & Putative Identity \\
\hline 34 & 2 & I & 5 & 8 & 8898 & 1665469 & 1665984 & 0 & $x$ & EAA09273 & $\operatorname{agCP}|4| 53$ & $1.00 \mathrm{E}-11 \mathrm{I}$ & $\begin{array}{c}\text { glutathione S- } \\
\text { transferase DII }\end{array}$ \\
\hline 35 & 0 & 4 & 3 & 7 & 8880 & 1407780 & 1408378 & 0 & $x$ & Q93113 & $\begin{array}{l}\text { glutathione S- } \\
\text { transferase I-6 }\end{array}$ & $1.00 \mathrm{E}-110$ & $\begin{array}{c}\text { glutathione S- } \\
\text { transferase I-6 }\end{array}$ \\
\hline 172 & 2 & 0 & 2 & 4 & 8816 & 4859270 & 4859540 & IE- 130 & $x$ & EAA05I08 & agCP6896 & 7E-65 & Glutaredoxin (GRXI) \\
\hline 307 & 0 & I & 0 & 1 & 8986 & 5275996 & 5276383 & IE-173 & $x$ & EAA00516 & agCP9336 & $8 E-46$ & copper ion transporter \\
\hline 620 & 0 & 0 & 2 & 2 & 8984 & 9812533 & 9812822 & $|E-16|$ & $x$ & AAL58538 & $\begin{array}{c}\text { glutathiones- } \\
\text { transferase E3 }\end{array}$ & IE-73 & $\begin{array}{l}\text { glutathione S- } \\
\text { transferase E3 }\end{array}$ \\
\hline 622 & 0 & 0 & 1 & 1 & 8980 & 538441 & 538745 & IE- $\mid 72$ & $x$ & AAF68382 & thioredoxin I & $5 E-49$ & $\begin{array}{l}\text { thioredoxin I } \\
\text { glutathione S- }\end{array}$ \\
\hline 704 & 0 & 0 & 1 & 1 & 8880 & 1406678 & 1407026 & 0 & $x$ & EAA08605 & agCP2490 & $4 E-36$ & transferase $1-6$ \\
\hline 909 & 0 & I & 0 & I & 8984 & 9810450 & 9810635 & $|E-10|$ & $x$ & AAG45I63 & $\begin{array}{c}\text { glutathiones- } \\
\text { transferase EI }\end{array}$ & $2 \mathrm{E}-20$ & $\begin{array}{c}\text { glutathione S- } \\
\text { transferase 3-I }\end{array}$ \\
\hline 910 & 0 & 0 & I & 1 & 8984 & 9809004 & 9809209 & IE- 108 & $x$ & AAG45I64 & $\begin{array}{c}\text { glutathiones- } \\
\text { transferase E2 }\end{array}$ & $6 E-28$ & $\begin{array}{c}\text { glutathione S- } \\
\text { transferase E2 }\end{array}$ \\
\hline 931 & 0 & 1 & 0 & 1 & 8933 & 621123 & 621383 & IE- $\mid 45$ & $x$ & EAA09899 & agCPII 759 & IE-73 & $\begin{array}{c}\text { Manganese } \\
\text { Superoxide dismutase } \\
I\end{array}$ \\
\hline $\begin{array}{c}101 \\
2\end{array}$ & 0 & 0 & 4 & 4 & 8849 & 2536282 & 2536794 & 0 & $x$ & EAA07I69 & agCPI0692 & $6 \mathrm{E}-80$ & $\begin{array}{c}\text { Superoxide dismutase } \\
3-D(C u, Z n)\end{array}$ \\
\hline $\begin{array}{c}104 \\
1\end{array}$ & 1 & 0 & 2 & 3 & 8849 & 1674668 & 1675054 & 0 & $x$ & EAA07207 & agCPI07I3 & IE-II5 & $\begin{array}{c}\text { glutathione S- } \\
\text { transferase SI-2 }\end{array}$ \\
\hline $\begin{array}{c}104 \\
2\end{array}$ & 0 & I & 2 & 3 & 8986 & 8102109 & 8102313 & IE- 105 & $x$ & EAA00332 & agCP9864 & $2 \mathrm{E}-90$ & $\begin{array}{l}\text { I-cys peroxiredoxin } \\
\text { TPX4 }\end{array}$ \\
\hline $\begin{array}{c}106 \\
5\end{array}$ & 0 & 0 & 3 & 3 & 8804 & 83740 & 83869 & $6 E-45$ & $N$ & A) 284424 & $\begin{array}{l}\text { 4A3B-AAW-E-09- } \\
\text { F A. gambiae } \\
\text { immune } \\
\text { competent 4A3B }\end{array}$ & $2 \mathrm{E}-5 \mathrm{I}$ & $\begin{array}{l}\text { 2-Cys thioredoxin } \\
\text { peroxidase TPX2 }\end{array}$ \\
\hline $\begin{array}{c}148 \\
2\end{array}$ & 0 & 0 & I & 1 & 8984 & 9812211 & 9812365 & $2 \mathrm{E}-74$ & $x$ & AAL58538 & $\begin{array}{c}\text { glutathiones- } \\
\text { transferase E3 }\end{array}$ & $8 E-06$ & $\begin{array}{c}\text { glutathione S- } \\
\text { transferase E3 } 2 \text {-Cys }\end{array}$ \\
\hline $\begin{array}{c}168 \\
4\end{array}$ & 0 & I & 0 & 1 & 8804 & 84431 & 84661 & $|E-| \mid 7$ & $x$ & EAA03855 & agCPI990 & $2 E-35$ & $\begin{array}{l}\text { thioredoxin peroxidase } \\
\text { TPX2 thioredoxin I }\end{array}$ \\
\hline $\begin{array}{c}190 \\
9\end{array}$ & 1 & 0 & 0 & 1 & 8980 & 539114 & 539324 & IE-109 & $N$ & AJ283949 & $\begin{array}{l}\text { 4A3B-AAH-C-12-F } \\
\text { A. gambiae } \\
\text { immune } \\
\text { competent 4A3B }\end{array}$ & IE- 107 & \\
\hline $\begin{array}{c}203 \\
3\end{array}$ & 1 & 0 & 0 & 1 & 8898 & 1672566 & $167317 \mid$ & 0 & $x$ & EAA09|47 & agCPI4|3| & IE- 120 & $\begin{array}{l}\text { glutathione S- } \\
\text { transferase D3 }\end{array}$ \\
\hline $\begin{array}{c}207 \\
8\end{array}$ & 1 & 0 & 0 & 1 & 8984 & 9807310 & 9807705 & 0 & $x$ & AAL59653 & $\begin{array}{c}\text { glutathiones- } \\
\text { transferase E4 }\end{array}$ & $4 E-7 I$ & $\begin{array}{c}\text { glutathione S- } \\
\text { transferase E4 }\end{array}$ \\
\hline $\begin{array}{c}212 \\
7\end{array}$ & 0 & 1 & 0 & 1 & 8986 & 8102593 & 8102854 & IE-13i6 & $x$ & EAA00332 & agCP9864 & $6 E-31$ & peroxiredoxin TPX4 \\
\hline $\begin{array}{c}215 \\
6\end{array}$ & 0 & 0 & 1 & 1 & 8880 & 3392447 & 3392665 & IE- 120 & $x$ & EAA08586 & agCP2356 & $2 \mathrm{E}-43$ & thioredoxin \\
\hline $\begin{array}{c}229 \\
6\end{array}$ & 0 & 0 & 1 & 1 & 8807 & 1924679 & 1924904 & IE-IIO & $x$ & EAA03983 & agCP3। 66 & $5 E-75$ & $\begin{array}{c}\text { thioredoxin peroxidase } \\
\text { TPX3 }\end{array}$ \\
\hline $\begin{array}{c}233 \\
4\end{array}$ & 1 & 0 & 0 & 1 & 8880 & $36 \mid 4672$ & 3614912 & IE-124 & $x$ & EAA08535 & agCP2389 & $3 \mathrm{E}-58$ & $\begin{array}{c}\text { glutathione peroxidase } \\
\qquad 2-A, 2-B\end{array}$ \\
\hline
\end{tabular}


Although GSTs are most often associated with the detoxification of xenobiotics they are also involved in a number of cellular processes including protection from oxidative stress and apoptosis [44]. In addition to regulating thioredoxin, GSTs regulate the redox state of pro-apoptotic proteins $[29,45]$ These redox-modulating enzymes may be inducing oxidative stress either in response to Plasmodiuminduced inflammation or to apoptosis of mosquito tissues. Thus, the generation and modulation of reactive oxygen species by multiple enzymes induced later in A. gambiae infection, which we now observe, may regulate or limit oocyst development.

Transcripts of 25 genes involved in insect immune responses were identified (Table 4). Previously characterized A. gambiae immune-related peptides included AS 1286, gram negative [bacteria] binding protein, GNBP; AS 2178, cecropinA, CecA; and AS 1197, cecropinB, CecB. Two ficolins, AS 1364 and AS 1922, and four lysozymes AS 32, AS 221, AS 659 and AS 2030, were also identified. GNBP, has been linked with the immune response to Plasmodium infection, had already been found to be induced in the 20-30 h following A. gambiae infection with $P$. berghei $[35,46]$

Cecropins are small, basic peptides which cause lysis of gram negative and some gram positive bacteria by forming pores in their inner cell membranes (see [47] for review). They have been found in a wide variety of insects, including many vectors of parasitic diseases. The A. gambiae genome contains either 3 or 4 cecropin genes $[48,49]$. The CecA gene product, Cecropin A, is induced by Plasmodium during the early stages of infection $[48,50]$. The divergently transcribed $C e c A$ and $C e c B$ genes are both upregulated in an A. gambiae cell line after challenge with lipopolysaccharide and heat-inactivated bacteria [49]. This induction is regulated by a currently uncharacterized NF B-class transcription factor. Since these two $\mathrm{Cec}$ genes were identified only in the IRB library, they may be involved specifically in anti-Plasmodium responses.

Ficolins are carbohydrate-binding proteins related to collectins, a class of innate immunity lectins involved in the phagocytic ingestion of apoptotic cells [51-53]. In vertebrate innate immune responses, ficolins initiate the lectin pathway of complement activation [54]. The two ficolins we identified showed highest amino acid identity to the Drosophila Ficolin 2 precursor, but they correspond to different A. gambiae gene products located on different chromosomes in silico. Since they were found only in the IRB library, it is likely that they are involved in Plasmodium recognition prior to immune activation unless recognition, which appears to involve multiple pattern recognition proteins, is progressive.
The lysosome contributes to cellular maintenance through involvement in autophagy and to immunity through protease-mediated degradation of phagocytosed substances and apoptosis-like programmed cell death [55]. Since all lysosomal enzymes identified in this study except for AS 32 were found solely in the IRB library, the increase in lysosomal proteases in the IRB library may be indicative of phagocytic, inflammatory, and/or apoptotic responses to Plasmodium infection. We identified transcripts of four different lysozyme genes among our ESTs. AS 32, for which we had 9 ESTs distributed in all three libraries, showed clear evidence of alternative splicing. This gene corresponds to the previously characterized basic lysozyme gene, ENSANGG00000019898 [56]. They had concluded that this gene was expressed much more abundantly in sugar-fed than in blood-fed A. gambiae. However, the primers they used for their RT-PCR would also have amplified transcripts from a more recently identified lysozyme gene, ENSANGG00000015399, agCP3675, (AD, unpublished), thus potentially confounding their results. AS 221, AS 659 and AS 2030, the three other lysozyme EST sequences corresponding to ENSANGG00000015399 ENSANGG00000015906 (agCP3967), and ENSANGG00000015950 (agCP3164) were all found at one EST each in the IRB library. Thus, among abdominal CDNAs expressed following an IRB, we have identified transcripts representing 4 of the 5 lysozyme genes and 5 of the 7 potential lysozyme transcripts encoded in the $A$. gambiae genome. It is interesting that all of the A. gambiae lysozyme genes are located close together in the same region of chromosome $2 \mathrm{~L}$ and that their promoters all contain potential binding sites for NFB -like transcription factors, as would be expected for pathogen-induced transcription. Since AS 221 has also been identified as being induced more than two-fold at $48 \mathrm{~h}$ after an uninfected blood meal in our microarray study [12], it is also possible that different lysozymes or combinations of lysozymes may act as antibacterial agents in A. gambiae following sugar and blood feeding.

Lysozymes were not identified as potential immunityrelated proteins by Christophides et al. [48]. However, Hultmark [57] suggested that lysozyme may well be an immune protein that acts synergistically with cecropin to release microbial surface components, since its activity increases in concert with cecropin activity in bacteria-challenged silk worm larvae [58]. Therefore it is possible that multiple A. gambiae lysozymes may act together with cecropin(s) in an anti-Plasmodium response. The overall complexity of lysozyme genes, transcripts, and potential induction patterns in A. gambiae suggest that their roles as immune mediators deserve additional study in this mosquito. 


\begin{tabular}{|c|c|c|c|c|c|c|c|c|c|c|c|c|c|}
\hline AS & \# S ESTs & \# RB ESTs & \# IRB ESTs & $\begin{array}{c}\text { Total \# } \\
\text { ESTs }\end{array}$ & $\begin{array}{l}\text { Genome } \\
\text { Scaffold }\end{array}$ & Start & End & E value & Blast Type & Accession & Blast Hit & E value & $\begin{array}{l}\text { Putative } \\
\text { Identity }\end{array}$ \\
\hline 28 & 17 & 3 & 0 & 20 & 8987 & 14943052 & 14943642 & 0 & $x$ & EAA0I 687 & agCPII956 & IE- $\mid 42$ & $\begin{array}{l}\text { serine } \\
\text { protease }\end{array}$ \\
\hline 32 & 2 & 3 & 4 & 9 & 8807 & 3383097 & 3383307 & $|E-1| 6$ & $x$ & Q17005 & $\begin{array}{l}\text { Lysozyme } \\
\text { precursor } \\
(\mathrm{I}, 4 \text {-beta-N- } \\
\text { acetylmura } \\
\text { midase) }\end{array}$ & $5 E-67$ & $\begin{array}{l}\text { lysozyme } \\
\text { precursor } \\
(\mathrm{I}, 4-\text { beta- } \mathrm{N} \text { - } \\
\text { acetylmura } \\
\text { midase) }\end{array}$ \\
\hline 68 & I & 0 & 0 & I & 8794 & 217313 & 217497 & IE- 100 & $x$ & EAA02509 & $\operatorname{agCPII665}$ & $3 E-13$ & $\begin{array}{l}\text { serine } \\
\text { protease } \\
\text { 14D2 }\end{array}$ \\
\hline 126 & 1 & 0 & 0 & 1 & 8964 & 2322618 & 2322792 & $2 \mathrm{E}-86$ & $x$ & EAAI $217 \mid$ & agCPI0937 & IE-25 & TEP3 \\
\hline 153 & 2 & 0 & 0 & 2 & 8986 & 8953596 & 8953709 & $4 E-45$ & $N$ & BM62I 296 & $\begin{array}{l}1700068744 \\
6469 \\
\text { A.Gam.ad.c } \\
\text { DNAI }\end{array}$ & $2 \mathrm{E}-63$ & fat-spondin \\
\hline 180 & I & 0 & 1 & 2 & 8859 & 3227518 & 3227913 & 0 & $x$ & EAA07758 & agCPIIII & $4 \mathrm{E}-70$ & $\begin{array}{l}\text { signal } \\
\text { transducer }\end{array}$ \\
\hline 221 & 0 & 0 & I & I & 8807 & 3388356 & 3388647 & IE-I58 & $x$ & EAA04406 & agCP3675 & $8 E-79$ & $\begin{array}{l}\text { lysozyme c- } \\
8\end{array}$ \\
\hline 418 & 1 & 0 & 3 & 4 & 8944 & 1827235 & 1827637 & 0 & $x$ & EAAI0I53 & agCPI5402 & $3 \mathrm{E}-64$ & gambicin \\
\hline 659 & 0 & 0 & 1 & I & 8807 & $3|40| 40$ & 3140290 & $5 E-80$ & $x$ & EAA04458 & agCP3967 & $3 E-56$ & $\begin{array}{l}\text { lysozyme c- } \\
4\end{array}$ \\
\hline 804 & 0 & 1 & 0 & 1 & 8960 & 17845546 & 17845795 & IE-139 & $x$ & CAA09389 & $\begin{array}{l}\text { ICHIT } \\
\text { protein }\end{array}$ & $5 E-31$ & ICHIT \\
\hline 832 & I & 0 & 1 & 2 & 8811 & $17 \mid 8220$ & $17 \mid 8532$ & $|E-| 5 \mid$ & $\mathrm{N}$ & BM635649 & $\begin{array}{l}1700068755 \\
9053 \\
\text { A.Gam.ad.c } \\
\text { DNAI }\end{array}$ & $3 E-64$ & AgToll \\
\hline 995 & 0 & 2 & 2 & 4 & 8960 & 23616 & 23997 & 0 & $x$ & EAAIIO0I & agCP570 I & IE-30 & $\begin{array}{l}\text { serine } \\
\text { protease }\end{array}$ \\
\hline 1049 & 0 & 2 & 0 & 2 & 8944 & 1995046 & 1995300 & IE- 138 & $x$ & EAAI0I38 & agCPI5205 & IE-78 & TEPI2 \\
\hline 1095 & 1 & I & 0 & 2 & 8960 & 16595875 & 16596267 & 0 & $x$ & EAAII 334 & agCP638I & $7 E-30$ & $\begin{array}{l}\text { signal } \\
\text { transducer }\end{array}$ \\
\hline 1120 & 0 & I & 1 & 2 & 8986 & 8676449 & 8676732 & IE-159 & $x$ & EAA004I4 & agCP9557 & $5 E-31$ & $\begin{array}{l}\text { serine } \\
\text { protease }\end{array}$ \\
\hline 1197 & 0 & 0 & 1 & 1 & 8847 & || $2362 \mid$ & II 23927 & IE-| 73 & $x$ & EAA06859 & agCP7366 & $3 E-25$ & Cecropin B \\
\hline 1286 & 0 & 0 & 1 & I & 8898 & 2844394 & 2844678 & IE- 149 & $x$ & EAA09116 & agCPI 4093 & $4 \mathrm{E}-28$ & GNBPBI \\
\hline 1364 & 0 & 0 & 1 & I & 8948 & 918161 & 918491 & IE-166 & $x$ & EAAI0406 & agCP2049 & $2 \mathrm{E}-54$ & ficolin \\
\hline 1616 & 0 & 1 & 0 & 1 & 8980 & 7957050 & 7957284 & IE-128 & $x$ & CAB90818 & $\begin{array}{l}\text { serine } \\
\text { protease }\end{array}$ & $7 E-79$ & $\begin{array}{l}\text { serine } \\
\text { protease }\end{array}$ \\
\hline 1701 & 0 & I & 0 & I & 8794 & 212210 & $2|253|$ & 0 & $x$ & AAB62929 & $\begin{array}{l}\text { serine } \\
\text { protease } \\
\text { I4D }\end{array}$ & $2 E-56$ & $\begin{array}{l}\text { serine } \\
\text { protease } \\
\text { I4D }\end{array}$ \\
\hline 1922 & 0 & 0 & 1 & 1 & 8816 & 1069890 & 1070396 & 0 & $x$ & EAA05160 & agCP6864 & $2 \mathrm{E}-55$ & ficolin \\
\hline 1997 & 1 & 0 & 0 & I & 8859 & 9665976 & 9666551 & 0 & $\mathrm{~N}$ & AF444782 & AgToll9 & $4 \mathrm{E}-06$ & AgToll9 \\
\hline 2030 & 0 & 0 & 1 & I & 8807 & 3137120 & 3137454 & 0 & $x$ & EAA04667 & $\operatorname{agCP} 3164$ & $3 E-82$ & $\begin{array}{l}\text { Lysozyme c- } \\
7\end{array}$ \\
\hline 2038 & 1 & 0 & 0 & 1 & 8975 & 72415 & 72691 & IE-I55 & $\mathrm{N}$ & AJ420785 & spi2 IF gene & |E-7| & $\begin{array}{l}\text { serpin } \\
\text { spi2IF }\end{array}$ \\
\hline 2178 & 0 & 0 & 1 & 1 & 8847 & 1121909 & | I 22047 & $6 \mathrm{E}-73$ & $x$ & EAA06858 & agCP7503 & $6 \mathrm{E}-21$ & Cecropin A \\
\hline
\end{tabular}


AS 418, Gambicin, transcripts were found in both the S and IRB libraries, insignificantly more in the latter (Table 4). The gambicin gene encodes a $6.8 \mathrm{kDa}$ antimicrobial peptide unique to A. gambiae [59]. Gambicin transcripts were found primarily, but not exclusively in the anterior midguts of both sugar-fed and blood-fed adult female mosquitoes. RT-PCR suggested that its transcription is induced slightly above basal levels at $30 \mathrm{~h} \mathrm{PBM}$ and by about 3 -fold by $24 \mathrm{~h}$ post infection, at which point $P$. berghei ookinetes are invading the midgut epithelium.

The association of AS804, ICHIT, a galectin with chitinlike domains, only with the RB library was unexpected. This is because ICHIT transcripts were found to be abundant in the midguts of sugar-fed adult female mosquitoes and only weakly induced in A. gambiae midguts $24 \mathrm{~h}$ PI with $P$. berghei [42].

Two Toll receptor gene transcripts were identified (Table 4 ). The Toll signal transduction pathway is involved both in insect immune responses, and, in Drosophila, at least, in specification of the dorsal-ventral body axis during embryogenesis. While there are 11 known Toll receptor genes in A. gambiae [48], the expression of only 4 has been characterized [60]. One, AS 832, corresponding to AgToll, was found only in the S and IRB libraries. Luna et al. [60] demonstrated that this gene is abundantly expressed in ovaries, and not at all in midgut. They also found that this gene is only weakly induced by bacterial challenge. This gene is actually duplicated in the A. gambiae genome as AgToll1 and AgToll1B, both of which are closely related to AgToll5A and AgToll5B, as well as to D. melanogaster Toll, DmToll1, encoding the receptor mediating body axis formation, and to DmToll5 [32].

Consequently, despite the fact that AS 832 was not found in the RB library, its primary function is more likely to be in embryogenesis than in defense. AS 1997, AgToll 9, was found only in the S library. It is abundantly and specifically expressed in midgut during multiple developmental stages [60], and is weakly induced in larvae by bacterial challenge, though it has not been tested for induction in Plasmodium-infected mosquitoes. It and its Drosophila ortholog, DmToll9, are most closely related to mammalian TLR genes, and may well be involved in immunity functions.

Serine proteases (SPs) and serine protease inhibitors (serpins, SRPNs) the inhibitors of SPs, function in multiple processes, of which immunity is only one. AS 68 , Sp 14D2; AS 28, SP G13; AS 153, fat-spondin; AS 2038, a serpin transcribed from the spi21F/SRPN10 locus, were all unique to the S library. The majority, 20/31, of SP transcripts identified, 17 of them derived from AS 28, SP G13, were from the S library (Table 4). Sp14D2 is abundantly expressed in adult females at 4 days post eclosion and is induced only slightly following bacterial challenge and $P$. berghei infection $[61,62]$. It may not be involved in immune responses. The adult gut-specific non-trypsin SP G13 is found in both blood fed and non-blood fed females, and is also immune responsive in bacterially challenged larvae [34]. The SRPN10 gene encodes four alternatively spliced transcripts which are differentially expressed in the midgut during development and following microbrial challenge [63]. We were unable to determine which one of these transcripts corresponds to AS 2038.

Four SPs were found in the RB library in addition to the previously described SP G13 (Table 4). These are AS 170, Sp14D1; AS 1616, CLIPB15; AS 1120, CLIPA7; and AS 995, agCP5701, previously predicted only computationally. Sp14D1 transcripts are expressed constitutively in multiple mosquito stages [62]. In adult females, they are expressed in the ovary and fat body, but not in the midgut. The Sp14D1 gene is induced by $24 \mathrm{~h}$ PBM and after a bacterial challenge. Therefore this serine protease may have roles both in development and in immunity. CLIPB15 showed significant induction following bacterial challenge and during malaria parasite invasion [48]. CLIPA7 and agCP5701 were found in both the RB and IRB libraries. CLIPA7 has not yet been characterized. However, the agCP5701 sequence shares identity with Ssp3, a serine protease recently identified in the hematophagous fly, Stomoxys calcitrans [64]. This serine protease colocalizes with defensin and is thought to activate it.

It is well known that insect immunity-effector genes are not necessarily induced by pathogen challenge, but instead, may be constitutively expressed in situations in which pathogens could be encountered. Certainly, defensin and lysozyme are constitutively expressed during blood feeding in ticks [65-68]. Thus several of the SP genes represented in our libraries may have immune functions, even though none is unambiguously upregulated following $P$. berghei infection.

Fat-spondin is a serine protease inhibitor of the Kunitz family that is down-regulated following septic injury. It is also regulated by Spaetzle, the activator of the Toll pathway in Drosophila [30,31]. Therefore mosquito fat-spondin may regulate immune responses during nectar feeding.

\section{Digital Northern and verification of selected gene expression patterns by $q R T-P C R$}

The complement of genes expressed in a cell or tissue represents its transcriptome [69]. Transcriptome analysis has been approached in several ways. Okubo et al. [5] demonstrated that a non-normalized, non-amplified cDNA 
library can faithfully represent the mRNA population in a tissue, and that such a resource could be used to explore the diverse array of active genes and their mRNA abundances in a tissue. Thus, the "digital Northern" became one of the first genome scale analytical methods employed in the study of gene expression. Three classes of mRNA transcript abundance were recognized based on reassociation kinetics; high abundance (5-15 mRNA species at $\sim 10,000$ copies per cell), intermediate abundance (500 species at $\sim 300$ copies per cell) and low abundance (10,000 different species at 1-15 copies per cell) [70-72]. Lee et al. [73] showed that in a random sample of approximately 3000 ESTs from a single cDNA library, > 99\% of highly abundant transcripts, $85 \%$ of intermediate abundance transcripts, and $<5 \%$ of low abundance transcripts should be represented at least once. Hwang et al. [4] demonstrated that differentially expressed genes could be identified digitally even in small data sets although the analysis would necessarily be restricted to more abundantly expressed transcripts, those that are expressed at a frequency of greater than 1 transcript in 800 .

Since our three cDNA libraries were neither normalized nor amplified, the number of ESTs in a contig should represent the abundance of the corresponding transcript in the libraries. Therefore we used the digital Northern technique to identify genes differentially expressed in the abdomens of A. gambiae females in response to a sugar meal, to a blood meal and to a blood meal containing infective malaria parasites. Although our investigation is necessarily limited to the analysis of moderately and highly abundant mRNAs, it offers a unique opportunity to identify a diverse array of transcripts and to examine some of the greater fluctuations in transcript abundance between and among libraries.

Although large EST sequencing experiments are not repeated and consequently do not exhibit variation, the number of ESTs corresponding to particular transcribed genes approximates a Poisson distribution [74]. Consequently two statistics, the Audic and Claverie Statistic and the R statistic, both based on a Poisson distribution, are used to evaluate the results of these experiments. The Audic and Claverie statistic is based on the assumptions that identifying any specific cDNA in a library is a rare event that represents one possible outcome of many, and that the total number of possible outcomes is unknown [7]. Confidence intervals, both $1 \%$ and $5 \%$, corresponding to the likelihood of selecting a specific species of cDNA among a subset of all possible cDNAs, are generated. The probability of selecting a specific clone is independent of sample size because the statistic accounts for differences in population size between libraries. This statistic becomes more reliable as the size of the sample analyzed increases. However, it is applicable only to pairwise comparisons and cannot be used to identify transcripts differentially expressed in more than two libraries. Stekel et al. [8] proposed using the $\mathrm{R}$ statistic to analyze the abundances of cDNAs in multiple libraries. The R statistic is a $\log$ likelihood ratio and similarly to the $\mathrm{C}^{2}$ distribution, its distribution is asymptotic. This log likelihood ratio is constructed from the likelihood of seeing an observed event, or in this case, the probability of selecting a specific species of $\mathrm{cDNA}$ from multiple libraries. It represents the differences in observed EST counts among multiple libraries as differences in gene expression levels rather than as random sampling variability.

Consequently we made pairwise comparisons in gene expression frequency using the Audic and Claverie Statistic and identified genes as differentially expressed among the three libraries using the R statistic. Contig sizes varied significantly (Figure 2). Almost half of the contigs contained only 2 ESTs, although the maximum number was 90. As expected, the number of contigs containing larger numbers of ESTs decreased exponentially in frequency as the number of contained ESTs increased.

Housekeeping genes are usually constitutively expressed in virtually all cell types of a multicellular organism even under a wide range of physiological and experimental circumstances [5]. Typically, though there are exceptions, they are also abundantly expressed. Thus, contigs represented in all three libraries and containing higher numbers of ESTs are most likely to represent transcripts encoding proteins involved in housekeeping functions. Contigs composed of more than 20 ESTs are described in Table 5. Indeed, 18/29 ASs, approximately $62 \%$ of contigs containing more than 20 ESTs, encode structural constituents of ribosomes. Unexpectedly, other genes commonly considered to housekeeping genes, such as those involved in oxidative phosphorylation, are not represented among these contigs. In fact, the most frequently identified gene products were AS 3, the A. gambiae agCP10095, and AS 1, a homolog of D. melanogaster LP07070, with 89 and 90 ESTs respectively. Surprisingly for abundant transcripts likely to encode housekeeping functions, there are currently no clues in the literature as to their functions. One potential clue is that transcription of AS 1 and AS 3 may be induced by $P$. berghei infection. It is also noteworthy that three of the contigs containing more than 20 ESTs, ASs 28,99 , and 18 , represent genes encoding serine-type endopeptidases. These enzymes all share high sequence identity with previously studied serine proteases and are differentially expressed among the three libraries (see below).

25 of the 149 contigs containing more than five ESTs represent cDNAs differentially expressed among the three libraries (Table 6). We detected three main patterns of 
expression among these genes. These include 1) up-regulation in the IRB library relative to any other library, 2) upregulation in both of the $\mathrm{RB}$ and IRB libraries relative to $\mathrm{S}$, and 3) down-regulation in the RB and IRB libraries and/ or up-regulation in the S library. Gene products up-regulated at $30 \mathrm{~h}$ PI with $P$. berghei included AS 996, agCP14019, an apparent cathepsin B; AS 230, Vitellogenin but not AS 447, the other vitellogenin gene 3 ' end contig (see below); AS 24, a probable vitelline membrane protein; AS 139, ribosomal protein L44; AS 475, mucin; AS 145, a high molecular weight (HMW) kininogen; AS 313, cytochrome c oxidase; and AS 270, which is similar to GenBank accession \#BM600177, an unknown gene product sequenced in the Celera Genomics A. gambiae EST project [1].

AS 996, a cathepsin B, sharing marginally-significant sequence identity with the Ae. aegypti vitellogenic cathepsin B-like protease, VCB, [75], also appeared to be upregulated in the IRB library. In Ae. aegypti, VCB is secreted maximally from the fat body at $24 \mathrm{~h} \mathrm{PBM}$ and accumulated by developing oocytes. During embryogenesis VCB degrades vitellin, the stored form of vitellogenin. qRTPCR of AS 996 showed that it is induced following a blood meal, and increased further in infected blood-fed mosquitoes in comparison with naïve blood-fed mosquitoes (Figure 3A). Ribeiro [15] also found using a digital Northern approach that this gene is up-regulated in whole adult female mosquitoes $24 \mathrm{~h}$ PBM. It is possible that the observed increase in this cathepsin $\mathrm{B}$ may be responsible for part of the decrease in vitellogenin protein observed late in the first gonotrophic cycle and during the second gonotrophic cycle following infection with Plasmodium [18]. It is also possible that this cathepsin B may have an immunity function.

Female mosquitoes synthesize large quantities of vitellogenin in the first day following a blood meal. Consequently, it was expected that the RB and IRB libraries would show increases in vitellogenin $(\mathrm{Vg})$ gene transcript abundance above the S library. Both AS 230 and AS 447 share sequence identity with $\mathrm{Vg}$ but represent non-overlapping sequences from the 5' and 3 ' ends of the genes, respectively. When these two contigs were analyzed together, $\mathrm{Vg}$ appeared to be expressed at significantly higher abundance in the RB library than in $\mathrm{S}$, as expected, and not to be repressed and/or degraded within $30 \mathrm{~h}$ of $P$. berghei infection (Table 6). This result is supported by qRT-PCR analysis (Figure 3B). Since Ahmed et al. [18] showed that $P$. yoelii nigeriensis infection of $A$. gambiae results in fecundity reduction, due, in part, to reduction in vitellogenin mRNA accumulation, we might have expected to see a slight, though statistically insignificant reduction in Vg mRNA abundance in the IRB library by 30 hr PBM, even at the lower temperature required for devel- opment of $P$. berghei $\left(19^{\circ} \mathrm{C}\right.$ vs. the $24^{\circ} \mathrm{C}$ used by Ahmed et al. ${ }^{2}$ analysis showed that AS 230 is expressed in significantly higher abundance than AS 447 in both the RB and IRB libraries, $0.05>\mathrm{P}>0.025$ and $\mathrm{P}<0.001$, respectively. However a goodness of fit test showed that the under-representation of $\mathrm{Vg}$ mRNA $3^{\prime}$ ends is exaggerated significantly in the IRB library, $G=26.3, P<0.01$ [76]. We can not currently explain this observation, except to suggest that Vg transcripts may be degraded from their 3' ends in response to Plasmodium infection.

S 24 also appears to be up-regulated in response to Plasmodium infection. BLASTN analysis showed that its nucleotide sequence is $96 \%$ identical to the A. gambiae transcript ENSANG00000021567, a gene product belonging to the vitelline membrane protein family. Insect orthologs of AS 24 include both the Drosophila Vm34Ca protein and the Ae. aegypti vitelline membrane protein 15A-1. In Ae. aegypti, 15A-1 mRNA is most abundant between 30 and $45 \mathrm{~h}$ PBM [77]. Our qRT-PCR analysis showed that this gene is induced following a blood meal (data not shown).

P. berghei invasion of An. stephensi midguts results in damage to invaded epithelial cells and their extrusion into the midgut lumen $[41,78]$. This may induce an inflammatory response. AS 475 is $100 \%$ identical at the amino acid level to the previously identified midgut-specific, membranebound mucin AgMuc1. Associated with the apical microvilli on the midgut, this mucin contains a putative GPIanchor and two hydrophobic domains. This result suggested that there may be a link between this membrane mucin and signal transduction following damage to the epithelium [79]. Membrane mucins also act as physical barriers protecting the free surface of the cell [80]. Therefore, increased mucin gene expression may serve as a protective response to parasitic invasion. Ribeiro [15] found that this mucin is up-regulated in blood-fed mosquitoes 24 h PBM [15]. Our qRT-PCR analysis showed no difference in gene expression PBM or PI (Figure 3C).

AS 145, putatively identified as agCP6338, contains a HMW kininogen protein domain. This domain is a signature for a family of similar inflammatory response proteins in vertebrates. HMW kininogen is a component of the vertebrate kinin system, a pathway involved in inflammation and pain responses to cell damage [44]. Both digital Northern analysis and qRT-PCR (Figure 4D) identified AS 145 as being induced only after Plasmodium infection. Damage to the midgut epithelium caused by invasion and penetration of $P$. berghei ookinetes may have been responsible for inducing AS145.

In contrast to other gene products induced in mosquito abdomens by infection with $P$. berghei, AS 170 appears to 


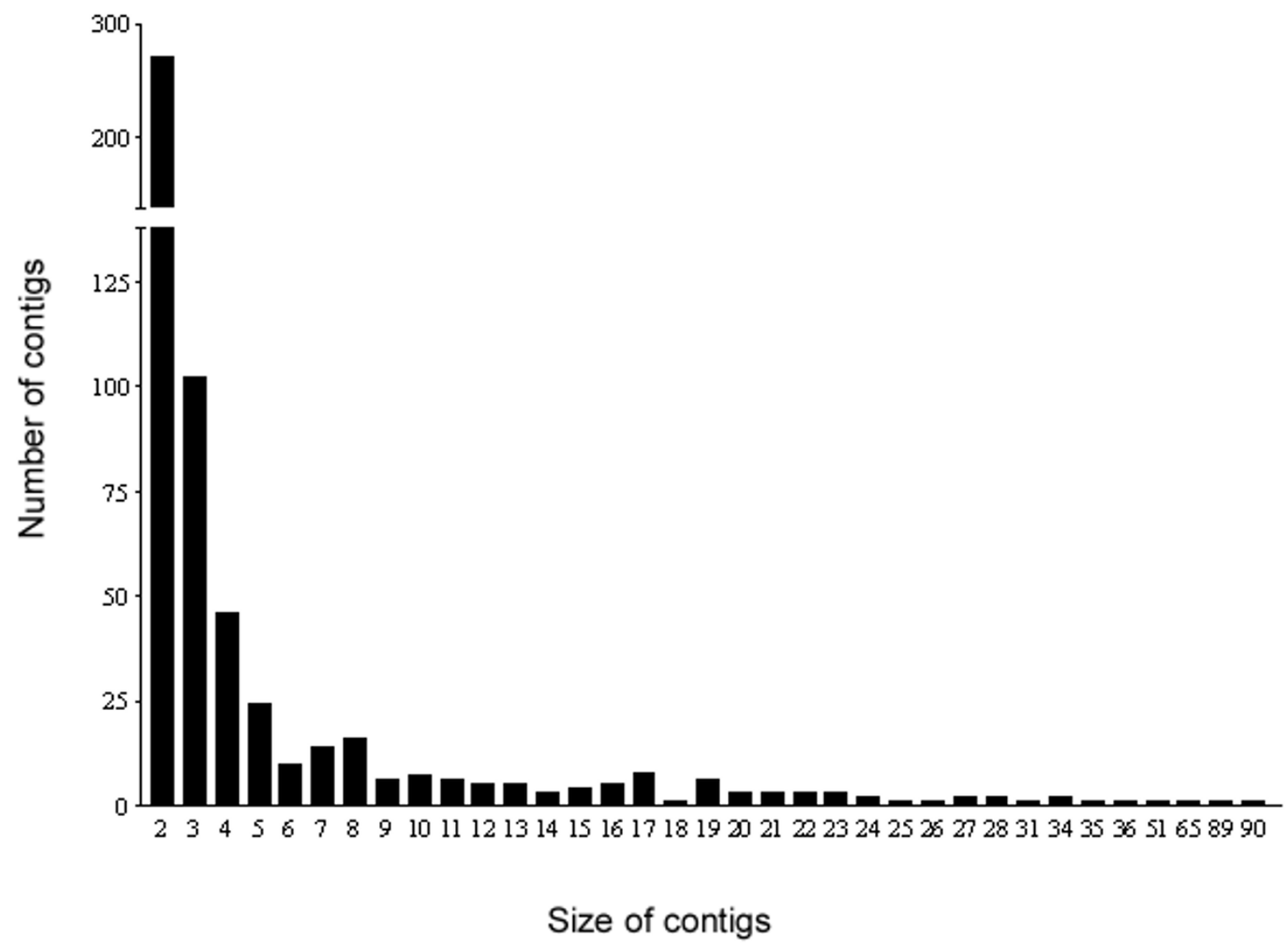

Figure 2

Transcript abundance distribution within the 567 multi-EST contigs of the S, RB and IRB libraries. The I408 singletons are not shown. Contig size $=$ the number of ESTs contained within it.

be repressed following a blood meal to levels below those found in sugar-fed females though it is well represented in the IRB library. This assembled sequence, which is derived completely from 5' UTR, not from protein-coding sequence, is highly identical to GenBank Accession \# BM653334, identified among their A. gambiae ESTs by Celera Genomics [1]. BM653334 was assembled into TC10892 in the TIGR gene indices, a tentative consensus sharing identity with the Drosophila $70-\mathrm{kDa}$ heat shock protein, Hsp70. Hsp70s are molecular chaperones highly conserved in all organisms. While Hsp70s are induced in response to heat shock and other stresses, they also function in many normal cellular processes including protein translation, translocation, folding and quality control, as well as repression of cell growth and apoptosis through specific protein-protein interactions [81]. Clearly, induction of this gene post IRB could be a stress response to Plasmodium infection. The interactions of mosquito Hsp70s with both mosquito and parasite proteins deserve further study.

Genes up-regulated following a blood meal could be divided into two groups, genes whose transcription is unaffected by $P$. berghei infection at $30 \mathrm{~h} \mathrm{PI}$, and genes whose transcription is apparently repressed. Gene products grouped into the first category include AS 98, hydrogen-transporting two-sector ATPase; AS 521, ribosomal protein L13; and AS 447, the second Vitellogenin 3' end contig. In contrast, gene products in the latter category include AS 35, glutathione S-transferase 1-6; AS 537, gly- 
Table 5: MOLECULAR FUNCTIONS OF CONTIGS CONTAINING > 20 ESTS.

\begin{tabular}{|c|c|c|c|c|c|c|c|}
\hline Contig & S ESTs & RB ESTs & IRB ESTs & Total ESTs & Blast Hit & Molecular Function & Organism \\
\hline 7 & 3 & 8 & 9 & 20 & agCPII398 & $\begin{array}{l}\text { structural constituent of } \\
\text { ribosome }\end{array}$ & A. gambiae \\
\hline 14 & 11 & 6 & 3 & 20 & agCPI538 & $\begin{array}{l}\text { structural constituent of } \\
\text { ribosome }\end{array}$ & A. gambiae \\
\hline 28 & 17 & 3 & 0 & 20 & agCPII 956 & serine-type peptidase & A. gambiae \\
\hline 140 & 5 & 6 & 10 & 21 & agCP7468 & $\begin{array}{l}\text { structural constituent of } \\
\text { ribosome }\end{array}$ & A. gambiae \\
\hline 167 & 11 & 4 & 6 & 21 & RpS27A & $\begin{array}{l}\text { structural constituent of } \\
\text { ribosome }\end{array}$ & D. melanogaster \\
\hline 516 & 8 & 10 & 3 & 21 & agCP3409 & peritrophin & A. gambiae \\
\hline 5 & 9 & 4 & 9 & 22 & agCP I 2023 & unknown & A. gambiae \\
\hline 20 & 13 & 5 & 4 & 22 & agCPI0687 & $\begin{array}{l}\text { structural constituent of } \\
\text { ribosome }\end{array}$ & A. gambiae \\
\hline 201 & 7 & 6 & 9 & 22 & agCP7935 & unknown & A. gambiae \\
\hline 8 & 15 & 5 & 3 & 23 & $\operatorname{agCP8I33}$ & $\begin{array}{l}\text { structural constituent of } \\
\text { ribosome }\end{array}$ & A. gambiae \\
\hline 13 & 16 & 2 & 7 & 23 & peritrophin I & peritrophin & A. gambiae \\
\hline 532 & 7 & 6 & 10 & 23 & agCPI729 & $\begin{array}{l}\text { structural constituent of } \\
\text { ribosome }\end{array}$ & A. gambiae \\
\hline 165 & 10 & 7 & 7 & 24 & agCP7766 & $\begin{array}{l}\text { structural constituent of } \\
\text { ribosome }\end{array}$ & A. gambiae \\
\hline 199 & 9 & 5 & 10 & 24 & agCP4384 & $\begin{array}{l}\text { structural constituent of } \\
\text { ribosome }\end{array}$ & A. gambiae \\
\hline 17 & 12 & 3 & 10 & 25 & agCP8340 & $\begin{array}{l}\text { structural constituent of } \\
\text { ribosome }\end{array}$ & A. gambiae \\
\hline 528 & 6 & 7 & 13 & 26 & agCP4228 & $\begin{array}{l}\text { structural constituent of } \\
\text { ribosome }\end{array}$ & A. gambiae \\
\hline 99 & 16 & 3 & 8 & 27 & $\operatorname{agCP} 3 \mid 23$ & $\begin{array}{l}\text { serine-type } \\
\text { endopeptidase }\end{array}$ & A. gambiae \\
\hline 230 & $\mathbf{I}$ & 7 & 19 & 27 & $\operatorname{agCP25} 18$ & vitellogenin & A. gambiae \\
\hline 139 & 6 & 5 & 17 & 28 & ebiP4I5 & $\begin{array}{l}\text { structural constituent of } \\
\text { ribosome }\end{array}$ & An. gambiae \\
\hline 229 & 8 & 9 & 11 & 28 & agCP8207 & $\begin{array}{l}\text { structural constituent of } \\
\text { ribosome }\end{array}$ & An. gambiae \\
\hline 18 & 25 & 2 & 4 & 31 & agCPII 264 & $\begin{array}{l}\text { serine-type } \\
\text { endopeptidase }\end{array}$ & A. gambiae \\
\hline 15 & 19 & 5 & 10 & 34 & Eflalpha48D & elongation factor & D. melanogaster \\
\hline 269 & 10 & 6 & 18 & 34 & agCP9994 & $\begin{array}{l}\text { structural constituent of } \\
\text { ribosome }\end{array}$ & A. gambiae \\
\hline 4 & 17 & 5 & 13 & 35 & agCP9893 & $\begin{array}{l}\text { structural constituent of } \\
\text { ribosome }\end{array}$ & A. gambiae \\
\hline 521 & 7 & 14 & 15 & 36 & agCP83I7 & $\begin{array}{l}\text { structural constituent of } \\
\text { ribosome }\end{array}$ & A. gambiae \\
\hline 91 & 13 & 12 & 26 & 51 & agCPII873 & $\begin{array}{l}\text { structural constituent of } \\
\text { ribosome }\end{array}$ & A. gambiae \\
\hline 228 & 19 & 16 & 30 & 65 & agCP9509 & $\begin{array}{l}\text { structural constituent of } \\
\text { ribosome }\end{array}$ & A. gambiae \\
\hline 3 & 31 & 21 & 37 & 89 & agCPI0095 & unknown & A. gambiae \\
\hline I & 27 & 19 & 44 & 90 & LP07070 & unknown & D. melanogaster \\
\hline
\end{tabular}


cine hydroxymethyltransferase; AS 273, ATP synthase b; and AS 516, Peritrophin 1.

AS 516 is $98 \%$ identical at the amino acid level to Peritrophin 1, a midgut peritrophic matrix (PM) protein, and maps in silico to the same location on chromosome $2 \mathrm{~L}$ as Peritrophin 1. Peritrophin 1 mRNA is present in sugar-fed females at 5 days post-eclosion, but is induced $12-24 \mathrm{~h}$ PBM [82]. Our digital Northern analysis showed that AS 516 is induced by at $30 \mathrm{~h}$ PBM, but repressed in response to Plasmodium infection. Ookinetes may partially inhibit PM formation, facilitating their penetration through it to gain access to the midgut epithelium. This is unsurprising, given that ookinetes produce locally-acting chitinases that are required for PM penetration and midgut invasion [83$85]$, and that they are targets for transmission blocking vaccines [86].

Almost half of the differentially expressed genes are downregulated PBM. AS 113 and AS 408, two unknown gene products; AS 13, a peritrophin-like protein; AS 18, Trypsin 1 ; and AS 99, Chymotrypsin 2, are significantly less abundantly expressed in the mosquito abdomen at $30 \mathrm{~h}$ PBM than in $\mathrm{S}$ females and not affected further by ookinete invasion. qRT-PCR (Figure 3E, see below) verifies this expression pattern for Chymotrypsin 2. Genes repressed PBM may also include a AS 591, a gene product with no known function but which is part of the mucin 4, tracheobronchial mucin fragment protein family, and AS 208, an ATP dependent RNA helicase, although the differences in abundance of these transcripts between $\mathrm{S}$ and $\mathrm{RB}$ are not statistically significant.

AS13 shares greatest amino acid identity with Peritrophin 1 . However, it shares greater nucleotide identity with ENSANGG00000020776, a gene located 4 kb downstream of Peritrophin 1, and is likely to have been derived from the latter. AS 18 and AS 99 share identity with two enzymes involved in digestion of the blood meal. AS 18 is $100 \%$ identical at the amino acid level to Trypsin 1 . Northern blots showed that transcripts of Trypsin 1, P35035, are present in adult female mosquitoes by $4 \mathrm{~h}$ PBM, increase rapidly until $12 \mathrm{~h}$, peak at $16 \mathrm{~h}$, remain at this plateau until $24 \mathrm{~h}$, then decrease steadily until $40 \mathrm{~h}$, and drop to baseline levels by $48 \mathrm{~h}$ PBM $[87,88]$. Trypsin 1 is also expressed in $\mathrm{S}$ females until 5 days post eclosion, but not at the high levels exhibited by Trypsin 4 [87]. Therefore it is not entirely clear why we found more transcripts of Trypsin 1 than of Trypsin 4 in the S library, and more in the S than in the $30 \mathrm{~h}$ PBM library. AS 99, another trypsin-like SP, is $97 \%$ identical to agCP3123, previously identified as the Chymotrypsin 2 precursor, Anchym2 [89]. This gene is expressed in the midgut at $12 \mathrm{~h} \mathrm{PBM}$ and remains abundant until $48 \mathrm{~h}$. Anchym2 transcripts are undetectable in $\mathrm{S}$ females. Using qRT-PCR, we found that
AS 99 transcript abundances are reduced in both RB and IRB mosquitoes relative to $S$ females (Figure 3E), though Ribeiro [15], also using transcript frequency analysis, found that both Trypsin 1 and Chymotrypsin 2 are up-regulated in whole adult female A. gambiae PBM. Since trypsin acitivity is known to be age-dependent in A. gambiae females [90], it is possible that these serine protease genes may be transcribed at higher levels in younger adult females than after the peak of proteolytic activity following a blood meal.

AS 28, agCP11956, SP G13, appears to be down-regulated PBM and further repressed following ookinete invasion. However it was shown not to be blood meal responsive in a previous study [34].

Housekeeping gene products involved in normal cellular maintenance may also be differentially expressed following septic injury. AS 28 and AS 170, the hsp70 homolog discussed above, are potential examples of two such proteins. Two assembled sequences corresponding to housekeeping genes up-regulated following $P$. berghei infection, AS 313 and AS 139, share sequence identity with a cytochrome c oxidase subunit and ribosomal protein L44, respectively. In contrast, the only housekeeping gene product down-regulated following $P$. berghei infection is AS 8 which shares amino acid identity with ribosomal protein L38e. The only gene identified as significantly more abundantly expressed in the mosquito abdomen PBM but unaffected by the presence of Plasmodium infection was AS 98, a hydrogen-transporting two-sector ATPase. Increased abundances of oxidative phosphorylation proteins may be linked to apoptosis or to increased metabolic demands placed on invertebrate hosts by invaders. The roles of these housekeeping gene products in immunity remain to be established.

Several A. gambiae genes identified in this study as being differentially regulated (Table 6) have potentially also been studied in microarray experiments performed in $A$. stephensi under generally similar experimental conditions $[17,37]$. Abraham et al. studied A. stephensi genes primarily from a cDNA library enriched for genes expressed in mosquito midguts containing early oocysts of $P$. berghei [17] and identified 226 EST contigs likely to have been of mosquito origin. None of these had clear identity with any of the putative differentially expressed A. gambiae genes in Table 6. Xu et al. studied A. stephensi genes differentially regulated between $6 \mathrm{~h}$ and $20 \mathrm{~d}$ PI with $P$. berghei [37]. Though the strategy used by $\mathrm{Xu}$ et al. in making the subtraction cDNA libraries assayed in the microarray was expected to have biased their identified mosquito genes towards ones upregulated PI and did bias mosquito genes towards ones upregulated between $20 \mathrm{~h}$ and $20 \mathrm{~d}$ PI, a chymotrypsin 2 precursor was identified as being 
Table 6: ASSEMBLED SEQUENCES WITH STATISTICALLY SIGNIFICANT DIGITAL NORTHERN VALUES

\begin{tabular}{|c|c|c|c|c|c|c|c|c|c|c|c|}
\hline AS & Sequence similarity; Description & $\mathbf{S}$ & $\mathbf{R B}$ & IRB & S (norm) & RB (norm) & IRB (norm) & AC S-RB & AC S-IRB & AC RB-IRB & $\mathbf{R}$ \\
\hline 996 & $\begin{array}{l}\text { agCPI40I9; similar to Aedes aegypti } \\
\text { vitellogenic cathepsin-B like protease } \\
\text { (VCB). }\end{array}$ & 0 & 0 & 5 & 0 & 0 & 29 & & 0.015 & 0.03 & 0.007 \\
\hline 24 & $\begin{array}{l}\text { no known predicted protein; shares } 96 \% \\
\text { nucleotide identity with transcript } \\
\text { ENSANG0000002 I567, a gene product } \\
\text { belonging to the vitelline membrane } \\
\text { protein family }\end{array}$ & 0 & 1 & 12 & 0 & 9 & 72 & 0.240 & 0 & 0.004 & 0 \\
\hline 139 & ebiP4I5; Ribosomal protein L44 & 6 & 5 & 17 & 35 & 44 & 102 & 0.132 & 0.005 & 0.017 & 0.034 \\
\hline 475 & agCPI2050; AgMucl & 2 & 3 & 12 & 12 & 26 & 72 & 0.138 & 0.002 & 0.024 & 0.012 \\
\hline 145 & $\begin{array}{l}\text { agCP6338; protein of unknown function } \\
\text { containing a HMW kininogen protein } \\
\text { domain }\end{array}$ & 1 & 2 & 8 & 6 & 18 & 48 & 0.172 & 0.008 & 0.046 & 0.034 \\
\hline 313 & CGI4235; Cytochrome c oxidase & I & 2 & 8 & 6 & 18 & 48 & 0.172 & 0.008 & 0.046 & 0.034 \\
\hline 270 & $\begin{array}{l}\text { no known predicted protein; shares } \\
\text { sequence identitiy with transcript } \\
\text { I } 700068705 \text { I I } 96 \text { A.Gam.ad.cDNA.blood } \\
\text { I of unknown function }\end{array}$ & 2 & 3 & 10 & 12 & 26 & 60 & 0.138 & 0.007 & 0.042 & 0.042 \\
\hline 230 & agCP25 I8; Vitellogenin I & 1 & 7 & 19 & 6 & 61 & $1 / 4$ & 0.005 & 0 & 0.024 & 0 \\
\hline 98 & $\begin{array}{l}\text { agCP4445; hydrogen-transporting two- } \\
\text { sector ATPase }\end{array}$ & 0 & 3 & 4 & 0 & 26 & 23 & 0.038 & 0.030 & 0.119 & 0.035 \\
\hline 521 & agCP83 I7; Ribosomal protein LI3 & 7 & 14 & 15 & $4 I$ & 122 & 90 & 0.005 & 0.018 & 0.043 & 0.039 \\
\hline 447 & agCP25 I8; Vitellogenin I & 0 & 10 & 8 & 0 & 87 & 48 & 0 & 0.002 & 0.034 & 0 \\
\hline 35 & Glutathione S-transferase DI-6 & 0 & 4 & 3 & 0 & 35 & 17 & 0.015 & 0.060 & 0.081 & 0.024 \\
\hline 537 & $\begin{array}{l}\text { agCP5224; Glycine } \\
\text { hydroxymethyltransferase }\end{array}$ & 0 & 5 & 2 & 0 & 44 & 11 & 0.006 & 0.123 & 0.034 & 0.009 \\
\hline 273 & $\begin{array}{l}\text { agCPI2503; ATP synthase B chain } \\
\text { mitochondrial precursor (FO-ATP } \\
\text { synthase subunit B) }\end{array}$ & 1 & 6 & 3 & 6 & 52 & 17 & 0.010 & 0.123 & 0.032 & 0.038 \\
\hline 516 & agCP3409; AgPerl & 8 & 10 & 3 & 46 & 87 & 17 & 0.046 & 0.045 & 0.003 & 0.029 \\
\hline 8 & agCP8I33; Ribosomal protein L38e & $\begin{array}{l}1 \\
4\end{array}$ & 6 & 3 & 81 & 52 & 17 & 0.076 & 0.003 & 0.032 & 0.025 \\
\hline 208 & agCP780 I; ATP dependent RNA helicase & 5 & 1 & 0 & 28 & 9 & 0 & 0.113 & 0.017 & 0.166 & 0.030 \\
\hline 28 & agCPI 1956; Serine protease GI3 & $\begin{array}{l}1 \\
7\end{array}$ & 3 & 0 & 98 & 26 & 0 & 0.008 & 0 & 0.027 & 0 \\
\hline 591 & $\begin{array}{l}\text { agCPI095; peptide with no known } \\
\text { function, is part of the protein Family } \\
\text { mucin } 4 \text { tracheobronchial mucin } \\
\text { fragment, shares weak identity to } \\
\text { Cryptosporidium parvum mucin-like } \\
\text { glycoprotein } 900\end{array}$ & 6 & 1 & 0 & 35 & 9 & 0 & 0.079 & 0.009 & 0.17 & 0.013 \\
\hline 113 & $\begin{array}{l}\text { agCPI0139; } 65 \text { aa peptide of unknown } \\
\text { function containing no known protein } \\
\text { domains except signal peptide and } \\
\text { transmembrane regions. }\end{array}$ & 8 & 0 & 0 & 46 & 0 & 0 & 0.010 & 0.002 & & 0 \\
\hline 18 & agCPII264; Trypsin I & $\begin{array}{l}2 \\
5\end{array}$ & 2 & 4 & 145 & 18 & 23 & 0 & 0 & 0.125 & 0 \\
\hline 408 & $\begin{array}{l}\text { I } 7000687367332 \text { A.Gam.ad.cDNAI; EST } \\
\text { of unknown function }\end{array}$ & 5 & 0 & 0 & 28 & 0 & 0 & 0.047 & 0.017 & & 0.008 \\
\hline 13 & $\begin{array}{l}\text { gene ENSANGG0000002077 6; gene } \\
\text { located } 4 \text { kb 3' to the Peritrophin I that } \\
\text { encodes a protein with a chitin binding } \\
\text { domain }\end{array}$ & $\begin{array}{l}1 \\
6\end{array}$ & 2 & 5 & 93 & 18 & 29 & 0.004 & 0.006 & 0.104 & 0.007 \\
\hline 99 & agCP3 I23; Chymotrypsin 2 & $\begin{array}{l}1 \\
6\end{array}$ & 3 & 8 & 93 & 26 & 48 & 0.01 & 0.025 & 0.069 & 0.054 \\
\hline 170 & $\begin{array}{l}\text { agCPI2309; putative homolog of } \\
\text { Drosophila melanogaster Heat shock } 70 \\
\text { kDa protein cognate } 4 \text { (Heat shock } 70 \\
\text { kDa protein } 88 \mathrm{E} \text { ) }\end{array}$ & 7 & 0 & 4 & $4 I$ & 0 & 23 & 0.017 & 0.086 & 0.050 & 0.028 \\
\hline
\end{tabular}

Actual EST counts (S, RB and IRB) and the normalized number of ESTs (S (norm), RB (norm), and IRB (norm)) are given for each cDNA library. Assembled sequences were identified as differentially expressed among the three libraries if the R statistic was less than 0.05 (Stekel et al. 2000 ). The Audic and Claverie statistic (AC < 0.05) was used to identify libraries in which the assembled sequence was statistically significantly differentially expressed (Audic and Claverie, I997). Pairwise comparisons between libraries are indicated by AC S-RB, AC S-IRB, and AC RB-IRB, respectively. All statistics were calculated with the IDEG6 Tool (Romualdi et al., 2003). Cells with characters in bold (underlined), bold (italics) and bold indicate statistical values equal to zero, less than $0.0 \mathrm{I}$, and less than 0.05 , respectively. Cells with characters in italics (only), represent different levels of gene expression ranging from no detectable transcripts (smallest) to I45 transcripts (largest) detected in a library. 

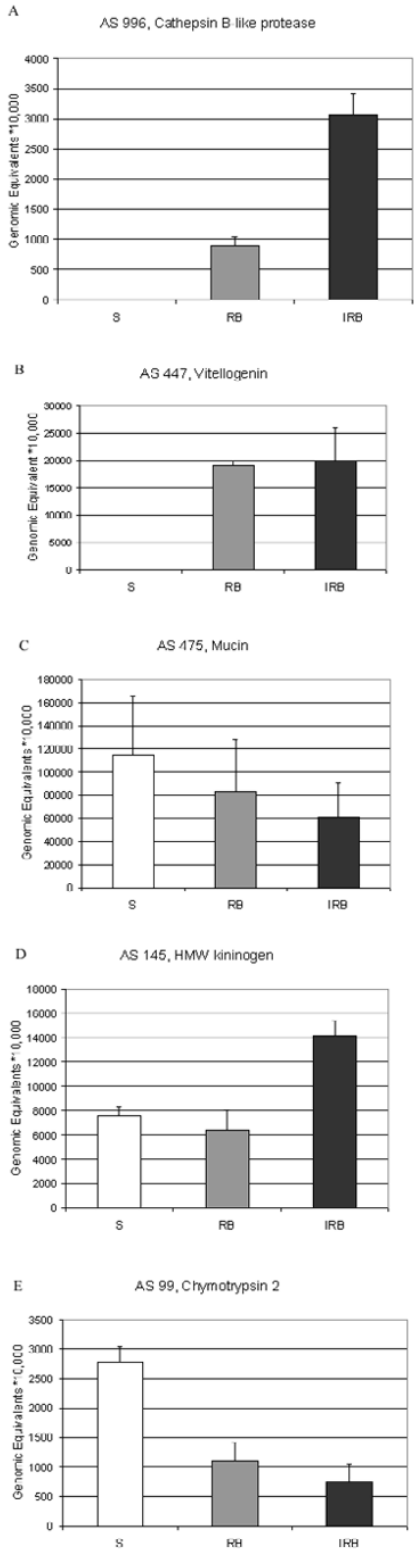

Figure 3

qRT-PCR of selected genes identified as differentially expressed in A. gambiae abdomens by digital Northern analysis. A. AS 996, a cathepsin B-like protease; B. AS 447, Vitellogenin; C. AS 475, Mucin; D. AS I45, a putative high molecular weight kininogen; and E. AS 99, Chymotrypsin 2. Transcript abundances were normalized against the abundance of RP S7 under the same condition and shown as genomic equivalents * I0,000 for S, RB, and P. berghei-infected (IRB) adult female mosquitoes $30 \mathrm{~h}$ post treatment. The arithmetic means of three biological replicates SEM are shown. ANOVA was used to compare the means, and a post hoc Tukey test was used to make pairwise comparisons. Statistically significant differences, $\mathrm{P}<0.05$ are discussed in the text. expressed more abundantly at earlier times than at later ones. Since their study did not include a $0 \mathrm{~h}$ PI time point, we cannot be certain that there is an actual discrepancy between our data and theirs. They found a peak in NOS activity at $40 \mathrm{~h}$ PI though we have no NOS ESTs with which to compare their data. Since Xu et al. did not test RNA from uninfected mosquitoes and tested only one time point, $20 \mathrm{~h}$, at all close to our $30 \mathrm{~h}$ we can not thoroughly evaluate the single identified gene overlap between the two data sets. In addition to the facts that experimental conditions varied among all three data sets and that at lease one of these data sets was small, it is possible that A. gambiae and A. stephensi have only partially overlapping repertoires of transcriptionally regulated responses to infection with $P$. berghei, simply because they are not extremely closely related anophelines. Though they are both classified within the subgenus Cellia, they are grouped differently within the subgenus, A. gambiae in the Pyretophorus series and A. stephensi among the Neocellia.

\section{Conclusion}

We have described 1975 genes expressed in the abdomens of adult female A. gambiae mosquitoes, $13 \%$ of which are not predicted by the genome sequence or by identity with known genes in other organisms. The latter provide important information for further A. gambiae genome annotation. All together these genes form a resource likely to be very useful for annotation of genes in other organisms. While D. melanogaster provides a model for many kinds of biological and bioinformatic analyses, its genome has been highly streamlined, more so than that of A. gambiae. Consequently, the A. gambiae genome and its associated genomic resources including its EST collections may sometimes prove more useful than Drosophila for annotation of genes in taxonomically distant organisms.

We have identified several genes as being induced following blood-feeding and/or $P$. berghei infection using the digital Northern technique. Limitations on this approach include the numbers of ESTs obtained from each library, the limited number of time points or physiological states that can be examined, and the requirement that their mRNAs be of intermediate or high abundance in at least one of the conditions studied. Thus some, indeed, many blood-feeding and immune-responsive genes may not have been identified, simply because they are expressed at low levels despite the importance of their roles in these processes. In addition, transcript abundances do not always correlate highly with protein levels. Some mRNAs have high turnover rates while others may be stabilized yet not translated except under specific conditions. Multiple, as well as more targeted approaches may be required before all gene products involved in responses to infection with Plasmodium are identified. Nevertheless, the ESTs 
obtained from the three different cDNA libraries have provided at least a rudimentary catalog of genes expressed in the abdomens of adult female A. gambiae harvested $30 \mathrm{~h}$ after they had fed on sugar, on blood or on blood infected with $P$. berghei. We should acknowledge some caution in the interpretation of cases where gene expression patterns in this study differ from those of comparison studies. This study was based on whole mosquito abdomens, which contain a multitude of organs, tissues and cell types and some comparison studies may involve either whole mosquitoes or subsets of the organs and tissues found in abdomens. Despite the limitations of the digital Northern portion of our study, we have identified several gene products as candidates for involvement in Plasmodium-immunity processes. These should be studied further. In addition, the sequences in the three cDNA libraries will certainly inform more detailed microarray and qRT-PCR studies of A. gambiae gene expression in both physiologically normal and Plasmodium-infected females.

\section{Methods}

\section{Mosquitoes and $P$. berghei infections}

Plasmodium infection susceptible (4arr) and transforming ookinete-encapsulating (L-35) strains of A. gambiae were reared under standard conditions $25^{\circ} \mathrm{C}, 70 \%$ humidity, $12 \mathrm{~h}$ light/dark. Adults were maintained on $20 \%$ sucrose until they were five to seven days post-eclosion. They were then blood fed on naïve and $P$. berghei-infected rats and maintained under similar conditions except that the temperature was lowered to $19-20^{\circ} \mathrm{C}$ to be permissive for development of $P$. berghei [91].

Female white rats (Rattus norvegicus) were maintained in the Freimann Life Sciences Center according to protocols established by the University of Notre Dame IUCAC. They were infected by intraperitoneal injection with $4 \times 10^{7} \mathrm{P}$. berghei gametocytes of the ANKA 2.34 clone (gift from Marcelo Jacobs-Lorena) suspended in 10\% DMSO. Rat parasitemia levels were determined from Giemsa-stained thin blood smears prepared from eye blood. Unfixed fresh eye blood samples were examined for gametocyte exflagellation, and exflagellation levels calculated as the number of events per 20 random microscopic fields at 400X magnification.

Female mosquitoes were blood fed on Plasmodiuminfected anaesthetized rats. To determine infection intensity and the time by which the majority of $P$. berghei ookinetes had penetrated to the basal lamina of the mosquito midgut epithelium and were transforming to oocysts, midguts of infected L-35 strain females were dissected in $1 \%$ formaldehyde in PBS at 30, 36 and 42 hours PBM, then transected longitudinally to remove the food bolus, washed in PBS and mounted flat on microscope slides $[92,93]$. Slides were examined microscopically and encap- sulated parasites counted using bright field illumination and $400 \times$ magnification. A two-way ANOVA was used to compare the mean numbers of parasites per midgut at the three times and a post hoc Tukey test was employed to detect differences in the means $[76,94]$.

\section{cDNA library construction}

5-7 day old female mosquitoes of the 4arr strain were 1) sugar fed (S library), 2) blood fed (RB library), and 3) $P$. berghei-infected (IRB library). Mosquitoes were immediately transferred to $20^{\circ} \mathrm{C}$ and incubated for 30 hours. Parasitemia of the rat used for these infections was $11.1 \%$. Mean mosquito infection prevalence was $83 \%$. The infection intensity ranged from 2 to 23 with an average of 9 parasites per midgut.

Blood and sugar-fed females were flash frozen in liquid nitrogen at $30 \mathrm{~h}$ PBM, or the equivalent age in the case of the $\mathrm{S}$ females, then vortexed at $-20^{\circ} \mathrm{C}$ to sever abdomens from heads and thoraces, similarly to [86]. Abdomens were collected at $-20^{\circ} \mathrm{C}$ and total RNA extracted using TRIzol (MRC, Inc.) according to the manufacturer's instructions. Poly- $\mathrm{A}^{+}$mRNA was isolated using the PolyA Tract mRNA Isolation System (Promega). S, RB and IRB cDNA libraries were constructed using the SMART ${ }^{\mathrm{TM}}$ CDNA Library Construction Kit (Clontech) from 1.54, 3.82 and $2.1 \mu \mathrm{g}$ of poly- $\mathrm{A}^{+}$mRNA, respectively. Unless otherwise stated, all reagents used were those provided in the kit. Reverse transcription of mRNA was for $1 \mathrm{hr}$ at $42^{\circ} \mathrm{C}$ using Superscript II Reverse Transcriptase (Invitrogen) and a modified oligo-dT primer, CDSIII/3' PCR Primer:5' ATTCTAGAGGCCGAGGCGGCCGACATG-d(T)30-3'(Invitrogen), to prime the first strand synthesis reaction. This primer contains the Sfi IB restriction site used for directional cloning. An additional oligonucleotide, either the SMARTIII $^{\mathrm{TM}}$ Oligonucleotide, 5'-AAGCAGTGGTATCAACGCAGAGTGGCCATTATGGCCGGG-3'(Slibrary), or the SMART IV TM Oligonucleotide, 5'-AAGCAGTGGTATCAACGCAGAGTGGCCATTACGGCCGGG-3'(RB and IRB libraries), contains the Sfi IA restriction site followed by 3 guanines. Second strand synthesis of cDNAs was conducted in a $100 \mathrm{l}$ volume with $11.0 \mathrm{l}$ first strand cDNA, 0.2 $\mathrm{M}$ of the indicated $5^{\prime}$ and $3^{\prime}$ oligonucleotides, $1 \mathrm{X}$ Advantage 2 PCR Buffer, 1X dNTP Mix, and 1X Advantage 2 Polymerase Mix. These reactions were performed on a Perkin-Elmer 9600 Thermocycler using the following cycling conditions: $72^{\circ} \mathrm{C}$ for $10 \mathrm{~min}, 95^{\circ} \mathrm{C}$ for $20 \mathrm{~s}$, followed by 3 cycles of $95^{\circ} \mathrm{C}$ for $5 \mathrm{~s}$ and $68^{\circ} \mathrm{C}$ for $8 \mathrm{~min}$. Primer extended cDNAs were visualized on an ethidium bromide stained $1.25 \%$ agarose, $1 \mathrm{X}$ TBE gel for quality assessment. They appeared as homogeneous smears ranging from 100 bp to $5 \mathrm{~kb}$. mRNA aliquots not used for cDNA synthesis and cloning were also subjected to PCR amplification using Taq Polymerase and visualized on the same gel. The absence of any visible product on the gel confirmed that 
genomic DNA did not contaminate these mRNA populations.

Following proteinase $\mathrm{K}$ digestion and phenol:chloroform extraction, the amplified cDNAs were digested with $10 \mu \mathrm{l}$ Sfi I $(20 \mathrm{U} / \mu \mathrm{l})$ at $50^{\circ} \mathrm{C}$ for $2 \mathrm{~h}$ and size fractionated using CHROMA SPIN-400 columns (Clontech). The first three to four fractions containing cDNAs longer than $500 \mathrm{bp}$ were pooled, ethanol precipitated, and concentrated in $4.0 \mathrm{l}$ nuclease free water (Gibco, UltraPure). These cDNAs were directionally cloned into Sfi I digested TripIEx2 (Clontech), and packaged using Gigapack III Gold Packaging Extract (Stratagene) according to the protocol provided. Packaged recombinant phages were incubated with log phase E. coli XL1-Blue cells (Stratagene), plated and library titers determined. All three libraries were plated at 100 and $1000 \mathrm{pfu} /$ plate.

White plaques were isolated and recombinant phages eluted overnight in $100 \mathrm{l}$ SM buffer $(0.1 \mathrm{M} \mathrm{NaCl}, 0.01 \mathrm{M}$ $\mathrm{MgSO}_{4} .7 \mathrm{H}_{2} \mathrm{O}, 0.05 \mathrm{M}$ Tris-HCl (pH 7.5), 0.01\% (w/v) gelatin). The inserts were amplified via PCR using $5^{\prime}$ and 3' vector specific primers; 5' LD Amplimer Primer, 5'CTCGGGAAGCGCGCCATTGTGTTGG-3' and 3' LD Amplimer Primer, 5'-ATACGACTCACTATAGGGCGAATTGGC-3' (Invitrogen). Amplification reactions contained $0.4 \mathrm{l}$ eluted phage, $0.03 \mathrm{pmol}$ of each primer, 1X Taq Polymerase Buffer (Invitrogen), $3 \mathrm{mM} \mathrm{MgCl}_{2}, 1$ $\mathrm{mM}$ of each dNTP, and 0.2 U Taq Polymerase (Invitrogen) in a total volume of $25 \mathrm{ml}$. Reactions were performed in 96-well plates on a Perkin-Elmer 9700 Thermocycler using the following cycling conditions; initial denaturation at $95^{\circ} \mathrm{C}$ for $5 \mathrm{~min}$, followed by 25 cycles of denaturation at $94^{\circ} \mathrm{C}$ for $30 \mathrm{~s}$ and annealing/elongation at $70^{\circ} \mathrm{C}$ for $2 \mathrm{~min}$, and a final elongation step at $68^{\circ} \mathrm{C}$ for $3 \mathrm{~min}$. Seven samples were chosen randomly from each 96-well plate amplified, and $5 \mathrm{ml}$ of the reaction was electrophoresed on an ethidium bromide stained $1 \%$ agarose, $1 \mathrm{X}$ TBE gel to confirm that the PCR was not contaminated and that no primer dimers could be visualized (data not shown). 704 PCR-amplified cDNA clone inserts were visualized on ethidium bromide stained $1 \%$ agarose, 1 X TBE gels, and their insert sizes determined using the KODAK Digital Science 1D software (Scientific Imaging Systems; data not shown).

\section{cDNA clone sequencing and EST assembly}

cDNA clones were picked at random from the S, RB and IRB abdomen libraries and their $5^{\prime}$ end sequences obtained through single-pass sequencing of the PCRamplified inserts using the ABI PRISM Big Dye Terminators 3.0 Cycle Sequencing kit (ABI). All sequencing reactions were performed in 384-well plates on a PerkinElmer 9700 Thermocycler using the following cycling conditions; initial denaturation at $94^{\circ} \mathrm{C}$ for $4 \mathrm{~min}$, fol- lowed by 25 cycles of denaturation at $94^{\circ} \mathrm{C}$ for $10 \mathrm{~s}$, annealing at $50^{\circ} \mathrm{C}$ for $5 \mathrm{~s}$, and elongation at $60^{\circ} \mathrm{C}$ for 4 min. Each reaction contained $0.7 \mathrm{ml}$ PCR product, 7.4 pmol of the 5' LD Amplimer Primer, $1 \times$ Sequencing Buffer (400 mM Tris pH 9.0, $10 \mathrm{mM} \mathrm{MgCl}_{2}$ ), and Big Dye (ABI) in a total volume of $7 \mathrm{ml}$. Reaction products were ethanol precipitated, resuspended in $20.0 \mathrm{ml}$ HiDi formamide (ABI) and electrophoresed on an ABI 3700 Sequencer.

Sequences were trimmed of low quality and vector sequence, then screened to remove mitochondrial sequences using the SeqMan II software (DNASTAR, Inc.), prior to contig assembly. The options employed for SeqMan II assembly were match size $=12$ bases, minimum match $\%=80$, minimum sequence length $=100$, maximum added gaps per $\mathrm{kb}$ in contig $=70$, maximum added gaps per $\mathrm{kb}$ in sequence $=70$, maximum register shift difference (maximum base pair separation) between matches $=70$, gap penalty $=0$, and gap length penalty $=$ 0.7. Consensus sequences derived from the alignment of multiple ESTs were defined as contigs, whereas ESTs that did not assemble into a cluster were defined as singletons. Consensus sequences were called by trace evidence, the majority percentage $=75$, using the quality weights option.

\section{Bioinformatic analysis}

Bioinformatic analysis was initiated by subjecting consensus contig and singleton sequences to several blast searches. Initially, sequences were tested against the $A$. gambiae genome using BLASTN 2.2.4 [95,96]. The significance cutoff was chosen as $\mathrm{E}<1 \times 10^{-4}$. Sequences were then tested against the non-redundant nucleotide database in GenBank using BLASTX 2.2.4, at the same URL. Sequences that failed to yield significant BLASTX matches were retested against the same database using BLASTN. Finally, sequences lacking any significant BLAST hits were tested against dbEST using BLASTN.

Gene product identities were inferred from BLAST hits and the annotations provided for A. gambiae and D. melanogaster clones in public databases including The Institute for Genomic Research (TIGR) Gene Indices [97] and GadFly Genome Annotation Database in FlyBase [98-100]. Putative molecular functions of the gene products were determined using KEGG [101] and assigned to categories established by the Gene Ontology Consortium, GOC $[102,103]$. Gene products were also assigned to hybrid biological process categories by combining the categories used by the GOC and by [1].

\section{Digital northerns}

Each contig represents an expressed gene and the number of sequences within a contig represents its transcript abundance. As in [104], only contigs containing more 
than five ESTs were used for transcript profiling. Gene expression profiles were created by tabulating the frequencies of cDNAs corresponding to a particular gene in each library and then compared among the three experimental groups. Genes were identified as differentially expressed using the R Statistic. Differences between libraries were determined using the Audic and Claverie pairwise comparison statistic calculated using IDEG6 [104].

\section{qRT-PCR}

Quantitative real-time PCR (qRT-PCR) analysis was performed using SYBR Green I (Applied Biosystems) technology in order to validate data obtained from the digital Northerns,. The Primer Express v. 1.5 software (Applied Biosystems) was used to design primer sets for the following 8 transcripts: AS 24 (Forward 5'-GAAGTAGCGAGAGACAGCATCGA-3', Reverse 5'TACGCTTCGGAGGTCAGTTACTG-3'); AS 99 (Forward 5'TTGCTGTCTCGGTACTCCTAG-3', Reverse 5'-GGTTGACGTAGTTGTCGTCCA-3'); AS 113 (Forward 5'-TGTTAGTCGCCCTGATGCTG-3', Reverse 5'TCAATGTTATGGGTACACCTTGTGT-3'); AS 145 (Forward 5'-TGGCGATCTTTGTCATCGTG-3', Reverse 5'-GATGACCGTGTTGACCACCAT-3'); AS 447 (Forward 5'TCCACTGCCGTGACGCT-3', Reverse 5'-TCCCTTGCGGATCTGCTG-3'); AS 475 (Forward 5'-TGCCCCACAGGATGTGAAA-3', Reverse 5'ATCGACATTGCCACGTATGC-3'); AS 996 (Forward 5'GTCGGGCGATTCCAATGA-3', Reverse 5'-TGTAACCGGGCTGGCAAA-3'); and the ribosomal protein S7 gene, RP S7, (Forward 5'-CATTCTGCCCAAACCGATG-3', Reverse 5'-AACGCGGTCTCTTCTGCTTG-3'). RP S7 [106] is the internal control currently most widely used in studies of A. gambiae gene expression [34,35,46,105]. All amplifications and fluorescence quantifications were performed using an ABI 7700 Sequence Detection System and associated Sequence Detector Software v. 1.7 (Applied Biosystems). Standard curves were generated using 10-fold serial dilutions of A. gambiae strain 4Arr genomic DNA extracted using the Qiagen DNeasy Tissue Kit protocol for animal tissues (Qiagen, Inc.). The DNA dilutions ranged from 115 to 0.0115 ng per reaction. Total RNA was extracted from rat blood-fed and P. bergheiinfected whole adult female mosquitoes using TRIzol (MRC, Inc.) RNA samples were incubated with $1.0 \mu \mathrm{l}$ of DNase I in the supplied DNase I buffer (Invitrogen) for 15 min at room temperature to remove contaminating DNA. The DNase I was then inactivated by addition of $4.0 \mu \mathrm{l}$ of 25 mM EDTA, pH 8.0 and the total RNA reisolated from TRIzol. RNA sample quality was evaluated by electrophoresis on $1 \%$ agarose, $1 \times$ TAE gels, and ethidium bromide staining of the gels. $5 \mathrm{~g}$ samples of RNA were reverse transcribed at $42^{\circ} \mathrm{C}$ for $1.5 \mathrm{~h}$ using Superscript II Reverse Transcriptase and oligo(dT) primer (both from Invitrogen) to prime first strand synthesis. qRT-PCR reactions were performed in duplicate in total volumes of $25 \mathrm{l}$ containing $12.5 \mathrm{l}$ of SYBR Green I PCR Master Mix, $300 \mathrm{nmol}$ of each gene-specific primer, $50 \mathrm{ng}$ of first strand cDNA template, and nuclease free water (Gibco, UltraPURE). All qRT-PCR reactions were performed using the following conditions: $50^{\circ} \mathrm{C}$ for $2 \mathrm{~min}$, then $95^{\circ} \mathrm{C}$ for $10 \mathrm{~min}$ followed by 45 cycles of denaturation at $95^{\circ} \mathrm{C}$ for $15 \mathrm{~s}$, annealing and extension at $60^{\circ} \mathrm{C}$ for $1 \mathrm{~min}$. Amplification plots were generated as fluorescence of SYBR Green I (Rn) vs. PCR cycle number using the Sequence Detector Software v. 1.7 (Applied Biosystems). The abundance of each gene product in an RNA sample was estimated from its standard curve and normalized against the RP S7 transcript abundance in the same RNA sample. Expression levels were represented as genomic equivalents $\times 10,000$. All comparisons were replicated on at least three biological samples, and the means and SEMs reported.

\section{Abbreviations}

AS, assembled sequence; bp, base pairs; EST, expressed sequence tag; GST, glutathione-S-transferase; h, hour; IRB, [Plasmodium-] infected red blood; kb, kilobases; min, minutes; nt, nucleotides; PBM, post blood meal; PI, postinfection; RB, rat blood; S, sugar, $20 \%$ sucrose; s, seconds; $\mathrm{SEM}$, standard error of the mean; $\mathrm{SP}$, serine protease; $\mathrm{Vg}$, vitellogenin.

\section{Authors' contributions}

AND carried out the study with contributions from PAR, MEH, NFL and MKK. PAR and AND drafted the manuscript with contributions from NFL and FHC. All authors read and approved the final manuscript.

\section{Additional material}

\section{Additional File 1}

Gene identification and ontology of EST contigs identified in this study. Click here for file

[http://www.biomedcentral.com/content/supplementary/1471-

2164-7-119-S1.xls]

\section{Acknowledgements}

We wish to thank Dr. Marcelo Jacobs-Lorena for his kind gift of Plasmodium berghei, James Hogan for mosquito rearing, Drs. Nora Besansky and Michael Ferdig for their constructive comments during the development of this research, and Dr. Rick Goetz and Priscilla Duman for assistance with technical aspects of cDNA library construction. This research would not have been possible without the assistance of the Freimann Life Sciences Center with animal care and Giemsa slide preparation. This project was supported by grants UOI-AI48846 and ROI-Al44273 from NIH/NIAID to F.H.C. Additional support was provided by a discovery grant to P.R. from the Natural Sciences and Engineering Research Council of Canada. 


\section{References}

I. Holt RA, Subramanian GM, Halpern A, Sutton GG, Charlab R, Nusskern DR, Wincker P, Clark AG, Ribeiro JM, Wides R, Salzberg SL, Loftus B, Yandell M, Majoros WH, Rusch DB, Lai Z, Kraft CL, Abril JF, Anthouard V, Arensburger P, Atkinson PW, Baden $\mathrm{H}$, de Berardinis V, Baldwin D, Benes V, Biedler J, Blass C, Bolanos R, Boscus D, Barnstead M, Cai S, Center A, Chaturverdi K, Christophides GK, Chrystal MA, Clamp M, Cravchik A, Curwen V, Dana A, Delcher A, Dew I, Evans CA, Flanigan M, Grundschober-Freimoser A, Friedli L, Gu Z, Guan P, Guigo R, Hillenmeyer ME, Hladun SL, Hogan JR, Hong YS Hoover J, Jaillon O, Ke Z, Kodira C, Kokoza E, Koutsos A, Letunic I, Levitsky A, Liang Y, Lin JJ, Lobo NF, Lopez JR, Malek JA, Mclntosh TC, Meister S, Miller J, Mobarry C, Mongin E, Murphy SD, O'Brochta DA Pfannkoch C, Qi R, Regier MA, Remington K, Shao H, Sharakhova MV, Sitter CD, Shetty J, Smith TJ, Strong R, Sun J, Thomasova D, Ton LQ, Topalis P, Tu Z, Unger MF, Walenz B, Wang A, Wang J, Wang M, Wang X, Woodford KJ, Wortman JR, Wu M, Yao A, Zdobnov EM, Zhang H, Zhao Q, Zhao S, Zhu SC, Zhimulev I, Coluzzi M, della Torre A, Roth CW, Louis C, Kalush F, Mural RJ, Myers EW, Adams MD, Smith HO, Broder S, Gardner MJ, Fraser CM, Birney E, Bork P, Brey PT, Venter JC, Weissenbach J, Kafatos FC, Collins FH, Hoffman SL: The genome sequence of the malaria mosquito Anopheles gambiae. Science 2002, 298(5591): I29-149.

2. Mongin E, Louis C, Holt RA, Birney E, Collins FH: The Anopheles gambiae genome: an update. Trends In Parasitology 2004 20(2):49-52.

3. Clegg N, Eroglu B, Ferguson C, Arnold H, Moorman A, Nelson PS: Digital expression profiles of the prostate androgenresponse program. Journal of Steroid Biochemistry and Molecular Biology 2002, 80(I): I3-23.

4. Hwang DM, Dempsey AA, Lee CY, Liew CC: Identification of differentially expressed genes in cardiac hypertrophy by analysis of expressed sequence tags. Genomics 2000, 66(I): I- | 4 .

5. Okubo K, Itoh K, Fukushima A, Yoshii J, Matsubara K: Monitoring Cell Physiology By Expression Profiles And Discovering CellType-Specific Genes By Compiled Expression Profiles. Genomics 1995, 30(2): I78-186.

6. Carulli JP, Artinger M, Swain PM, Root CD, Chee L, Tulig C, Guerin J, Osborne M, Stein G, Lian J, Lomedico PT: High throughput analysis of differential gene expression. Journal of Cellular Biochemistry 1998:286-296.

7. Audic S, Claverie JM: The significance of digital gene expression profiles. Genome Research 1997, 7( I 0):986-995

8. Stekel DJ, Git Y, Falciani F: The comparison of gene expression from multiple cDNA libraries. Genome Research 2000, I O( I 2):2055-206I.

9. Clements AN: The Biology of Mosquitoes. Volume I. London: Chapman \& Hall; 1992.

10. Raikhel AS: Hormonal control of reproductive processes. In Comprehensive Molecular Insect Science Volume 3. Edited by: Gilbert LI, latrou K, Gill SS. Oxford: Elsevier Pergamon; 2004:433-49l.

II. Romoser WS: The vector alimentary system. In The Biology of Disease Vectors Edited by: Beaty BJ, Marquardt WC. Niwot CO: University Press of Colorado; 1996:298-317.

12. Dana AN, Hong YS, Kern MK, Hillenmeyer ME, Harker BW, Lobo NF, Hogan JR, Romans P, Collins FH: Gene expression patterns associated with blood-feeding in the malaria mosquito Anopheles gambiae. BMC Genomics 2005, 6:5.

13. Marinotti O, Nguyen QK, Calvo E, James AA, Ribeiro JMC: Microarray analysis of genes showing variable expression following a blood meal in Anopheles gambiae. Insect Molecular Biology 2005, | 4(4):365-373.

14. Prevot Gl, Laurent-Winter C, Rodhain F, Bourgouin C: Sex-specific and blood meal-induced proteins of Anopheles gambiae midguts: analysis by two-dimensional gel electrophoresis. Malaria Journal 2003, 2: I.

15. Ribeiro JMC: A catalogue of Anopheles gambiae transcripts significantly more or less expressed following a blood meal. Insect Biochemistry and Molecular Biology 2003, 33(9):865-882.

16. Sanders HR, Evans AM, Ross LS, Gill SS: Blood meal induces global changes in midgut gene expression in the disease vector, Aedes aegypti. Insect Biochemistry and Molecular Biology 2003, 33(I I): I I05-II 22.

17. Abraham EG, Islam S, Srinivasan P, Ghosh AK, Valenzuela JG, Ribeiro JMC, Kafatos FC, Dimopoulos G, Jacobs-Lorena M: Analysis of the Plasmodium and Anopheles transcriptional repertoire dur- ing ookinete development and midgut invasion. Journal of Biological Chemistry 2004, 279(7):5573-5580.

18. Ahmed AM, Maingon R, Romans P, Hurd H: Effects of malaria infection on vitellogenesis in Anopheles gambiae during two gonotrophic cycles. Insect Molecular Biology 200 I, I 0(4):347-356.

19. Collins FH, Sakai RK, Vernick KD, Paskewitz S, Seeley DC, Miller LH, Collins WE, Campbell CC, Gwadz RW: Genetic Selection Of A Plasmodium-Refractory Strain Of The Malaria Vector Anopheles gambiae. Science 1986, 234(4776):607-610.

20. Lowenberger CA, Kamal S, Chiles J, Paskewitz S, Bulet P, Hoffmann JA, Christensen BM: Mosquito - Plasmodium interactions in response to immune activation of the vector. Experimental Parasitology 1999, 9 I(I):59-69.

21. Ensembl Mosquito Genome [http://www.ensembl.org/ Anopheles gambiae]

22. Boguski MS, Tolstoshev CM, Bassett DE: Gene Discovery In dbEST. Science 1994, 265(5 I 8 I): I993-1994.

23. Whitfield CW, Band MR, Bonaldo MF, Kumar CG, Liu L, Pardinas JR, Robertson HM, Soares MB, Robinson GE: Annotated expressed sequence tags and cDNA microarrays for studies of brain and behavior in the honey bee. Genome Research 2002, I 2(4):555-566

24. ClustalW WWW Service at the European Bioinformatics Institute [http://www.ebi.ac.uk/clustalw/]

25. Thompson JD, Higgins DG, Gibson TJ: Clustal-W - Improving The Sensitivity Of Progressive Multiple Sequence Alignment Through Sequence Weighting, Position-Specific Gap Penalties And Weight Matrix Choice. Nucleic Acids Research 1994, 22(22):4673-4680

26. Mathe C, Sagot MF, Schiex T, Rouze P: Current methods of gene prediction, their strengths and weaknesses. Nucleic Acids Res 2002, 30(19):4103-4II7.

27. Adams MD, Kelley JM, Gocayne JD, Dubnick M, Polymeropoulos MH, Xiao H, Merril CR, Wu A, Olde B, Moreno RF, Kerlavage AR, McCombie WR, Venter JC: Complementary-DNA Sequencing Expressed Sequence Tags And Human Genome Project. Science |99|, 252(5013): |65|-|656.

28. Misra S, Crosby MA, Mungall CJ, Matthews BB, Campbell KS, Hradecky P, Huang Y, Kaminker JS, Millburn GH, Prochnik SE, Smith CD, Tupy JL, Whitfied EJ, Bayraktaroglu L, Berman BP, Bettencourt BR, Celniker SE, de Grey AD, Drysdale RA, Harris NL, Richter J, Russo S, Schroeder AJ, Shu SQ, Stapleton M, Yamada C, Ashburner M, Gelbart WM, Rubin GM, Lewis SE: Annotation of the Drosophila melanogaster euchromatic genome: a systematic review. Genome Biol 2002, 3:12

29. Sheehan D, Meade G, Foley VM, Dowd CA: Structure, function and evolution of glutathione transferases: implications for classification of non-mammalian members of an ancient enzyme superfamily. Biochemical Journal 200I, 360:I-I6.

30. De Gregorio E, Spellman PT, Rubin GM, Lemaitre B: Genome-wide analysis of the Drosophila immune response by using oligonucleotide microarrays. Proceedings of the National Academy of Sciences of the United States of America 200I, 98(22): I2590-12595.

31. De Gregorio E, Spellman PT, Tzou P, Rubin GM, Lemaitre B: The Toll and Imd pathways are the major regulators of the immune response in Drosophila. EMBO Journal 2002, 2 I ( I I ):2568-2579.

32. Imler JL, Zheng LB: Biology of Toll receptors: lessons from insects and mammals. Journal of Leukocyte Biology 2004, 75(1): 18-26.

33. Irving P, Troxler L, Heuer TS, Belvin M, Kopczynski C, Reichhart JM, Hoffmann JA, Hetru C: A genome-wide analysis of immune responses in Drosophila. Proceedings of the National Academy of Sciences of the United States of America 2001, 98(26): I5II9-15124.

34. Dimopoulos G, Richman A, dellaTorre A, Kafatos FC, Louis C: Identification and characterization of differentially expressed cDNAs of the vector mosquito, Anopheles gambiae. Proceedings of the National Academy of Sciences of the United States of America |996, 93(23): | 3066-I307|

35. Dimopoulos G, Richman A, Muller HM, Kafatos FC: Molecular immune responses of the mosquito Anopheles gambiae to bacteria and malaria parasites. Proceedings of the National Academy of Sciences of the United States of America 1997, 94(2I): II508-II5I3.

36. Dimopoulos G, Christophides GK, Meister S, Schultz J, White KP Barillas-Mury C, Kafatos FC: Genome expression analysis of 
Anopheles gambiae : Responses to injury, bacterial challenge, and malaria infection. Proceedings of the National Academy of Sciences of the United States of America 2002, 99(13):8814-88I9.

37. Xu X, Dong Y, Abraham EG, Kocan A, Srinivasan P, Ghosh AK, Sinden RE, Ribeiro JM, Jacobs-Lorena M, Kafatos FC, Dimopoulos G: Transcriptome analysis of Anopheles stephensi-Plasmodium berghei interactions. Molecular and Biochemical Parasitology 2005, I 42(1):76-87.

38. Nappi AJ, Ottaviani E: Cytotoxicity and cytotoxic molecules in invertebrates. Bioessays 2000, 22(5):469-480.

39. Nappi AJ, Sugumaran M: Some biochemical aspects of eumelanin formation in insect immunity. In Insect Immunity Volume 48. Edited by: Pathak JPN. London: Kluwer; 1993:I3I-I48.

40. Luckhart S, Vodovotz Y, Cui LW, Rosenberg R: The mosquito Anopheles stephensi limits malaria parasite development with inducible synthesis of nitric oxide. Proceedings of the National Academy of Sciences of the United States of America 1998 95(1 0):5700-5705.

41. Han YS, Thompson J, Kafatos FC, Barillas-Mury C: Molecular interactions between Anopheles stephensi midgut cells and Plasmodium berghei: the time bomb theory of ookinete invasion of mosquitoes. Embo Journal 2000, 19(22):6030-6040.

42. Dimopoulos G, Seeley D, Wolf A, Kafatos FC: Malaria infection of the mosquito Anopheles gambiae activates immune-responsive genes during critical transition stages of the parasite life cycle. Embo Journal I998, I7(2I):6II5-6I23.

43. Tahar R, Boudin C, Thiery I, Bourgouin C: Immune response of Anopheles gambiae to the early sporogonic stages of the human malaria parasite Plasmodium falciparum. Embo Journal 2002, 2 I (24):6673-6680.

44. Cotran RS, Kumar V, Collins T: Robbins Pathological Basis of Disease. 6th edition. Philadelphia: WB Saunders; 1999.

45. Fernandez-Checa JC: Redox regulation and signaling lipids in mitochondrial apoptosis. Biochemical and Biophysical Research Communications 2003, 304(3):47I-479.

46. Richman AM, Dimopoulos G, Seeley D, Kafatos FC: Plasmodium activates the innate immune response of Anopheles gambiae mosquitoes. EMBO Journal 1997, I6(20):6II4-6II9.

47. Paskewitz SM, Christensen BM: Immune responses of vectors. In The Biology of Disease Vectors Edited by: Beaty BJ, Marquardt WC. Niwot CO: University Press of Colorado; 1996:37I-392.

48. Christophides GK, Zdobnov E, Barillas-Mury C, Birney E, Blandin S, Blass C, Brey PT, Collins FH, Danielli A, Dimopoulos G, Hetru C, Hoa NT, Hoffmann JA, Kanzok SM, Letunic I, Levashina EA, Loukeris TG Lycett G, Meister S, Michel K, Moita LF, Muller HM, Osta MA, Paskewitz SM, Reichhart JM, Rzhetsky A, Troxler L, Vernick KD, Vlachou D, Volz J, von Mering C, Xu J, Zheng L, Bork P, Kafatos FC: Immunity-related genes and gene families in Anopheles gambiae. Science 2002, 298(559I): 159-165.

49. Zheng $X L$, Zheng L: Genomic organization and regulation of three Cecropin genes in Anopheles gambiae. Insect Molecular Biology 2002, II (6):5 I7-525.

50. Vizioli J, Bulet P, Charlet M, Lowenberger C, Blass C, Muller HM Dimopoulos G, Hoffmann J, Kafatos FC, Richman A: Cloning and analysis of a cecropin gene from the malaria vector mosquito, Anopheles gambiae. Insect Molecular Biology 2000, 9(I):75-84.

51. Lu JH, Teh C, Kishore U, Reid KBM: Collectins and ficolins: sugar pattern recognition molecules of the mammalian innate immune system. Biochimica et Biophysica Acta-General Subjects 2002, I 572(2-3):387-400

52. Reid KB, Colomb M, Petry F, Loos M: Complement component $\mathrm{CI}$ and the collectins-first-line defense molecules in innate and acquired immunity. Trends Immunol 2002, 23: I I5-II 7.

53. Vandivier RW, Ogden CA, Fadok VA, Hoffmann PR, Brown KK Botto M, Walport MJ, Fisher JH, Henson PM, Greene KE: Role of surfactant proteins $D, D$, and $C l q$ in the clearance of apoptotic cells in vivo and in vitro: Calreticulin and CD9 I as a common collectin receptor complex. Journal of Immunology 2002, I69(7):3978-3986.

54. Matsushita M, Fujita $\mathrm{T}$ : The role of ficolins in innate immunity. Immunobiology 2002, 205(4-5):490-497.

55. Zakeri Z, Bursch W, Tenniswood M, Lockshin RA: Cell-Death Programmed, Apoptosis, Necrosis, or Other. Cell Death and Differentiation 1995, 2(2):87-96.
56. Kang DW, Romans P, Lee JY: Analysis of a lysozyme gene from the malaria vector mosquito, Anopheles gambiae. Gene 1996, I 74(2):239-244.

57. Hultmark D: Insect lysozymes. In Lysozymes: Model Enzymes in Biochemistry and Biology Basel JP: Birkhauser; 1996:87-102.

58. Morishima I, Horiba T, lketani M, Nishioka E, Yamano Y: Parallel induction of cecropin and lysozyme in larvae of the silkworm, Bombyx mori. Developmental And Comparative Immunology 1995, 19(5):357-363.

59. Vizioli J, Bulet P, Hoffmann JA, Kafatos FC, Muller HM, Dimopoulos G: Gambicin: A novel immune responsive antimicrobial peptide from the malaria vector Anopheles gambiae. Proceedings of the National Academy of Sciences of the United States of America 200I, 98(22): $12630-12635$

60. Luna C, Wang XL, Huang YM, Zhang JA, Zheng LB: Characterization of four Toll related genes during development and immune responses in Anopheles gambiae. Insect Biochemistry and Molecular Biology 2002, 32(9): I I7I- II79.

61. Gorman MJ, Andreeva OV, Paskewitz SM: Molecular characterization of five serine protease genes cloned from Anopheles gambiae hemolymph. Insect Biochemistry and Molecular Biology 2000, 30(I):35-46

62. Paskewitz SM, Reese-Stardy S, Gorman MI: An easter-like serine protease from Anopheles gambiae exhibits changes in transcript abundance following immune challenge. Insect Molecular Biology 1999, 8(3):329-337.

63. Danielli A, Kafatos FC, Loukeris TG: Cloning and characterization of four Anopheles gambiae serpin isoforms, differentially induced in the midgut by Plasmodium berghei invasion. Journal of Biological Chemistry 2003, 78(6):4 I 84-4| 93.

64. Hamilton JV, Munks RJL, Lehane SM, Lehane MJ: Association of midgut defensin with a novel serine protease in the bloodsucking fly Stomoxys calcitrans. Insect Molecular Biology 2002, I I(3): 197-205.

65. Grunclova L, Fouquier H, Hypsa V, Kopacek P: Lysozyme from the gut of the soft tick Ornithodoros moubata : the sequence, phylogeny and post-feeding regulation. Developmental and Comparative Immunology 2003, 27(8):65I-660.

66. Nakajima $Y$, Natori S: Identification and characterization of an anterior fat body protein in an insect. Journal of Biochemistry 2000, I 27(5):90I-908.

67. Nakajima Y, van Naters-Yasui AV, Taylor D, Yamakawa M: Two isoforms of a member of the arthropod defensin family from the soft tick, Ornithodoros moubata (Acari: Argasidae). Insect Biochemistry and Molecular Biology 200I, 3 I (8):747-75I.

68. Nakajima Y, van Naters-Yasui AV, Taylor D, Yamakawa M: Antibacterial peptide defensin is involved in midgut immunity of the soft tick, Ornithodoros moubata. Insect Molecular Biology 2002, II(6):6II-6I8

69. Velculescu VE, Zhang L, Zhou W, Vogelstein J, Basrai MA, Bassett DE, Hieter P, Vogelstein B, Kinzler KW: Characterization of the yeast transcriptome. Cell 1997, 88(2):243-25I

70. Alberts B, Bray D, Lewis J, Raff M, Roberts K, Watson JD: Molecular Biology of the Cell. New York: Garland; 1994.

71. Bishop JO, Morton JG, Rosbash M, Richardon M: Three abundance classes in HeLa cell messenger RNA. Nature 1974, 250:199-204.

72. Hastie ND, Bishop JO: The expression of three abundance classes of messenger RNA in mouse tissues. Cell 1976, 9:76I-774.

73. Lee NH, Weinstock KG, Kirkness EF, Earlehughes JA, Fuldner RA, Marmaros S, Glodek A, Gocayne JD, Adams MD, Kerlavage AR: Comparative Expressed-Sequence-Tag Analysis Of Differential Gene-Expression Profiles In Pc-12 Cells Before And After Nerve Growth-Factor Treatment. Proceedings of the National Academy of Sciences of the United States of America 1995, 92( I 8):8303-8307.

74. Claverie JM: Computational methods for the identification of differential and coordinated gene expression. Human Molecular Genetics 1999, 8(10): I82 I-1832

75. Cho WL, Tsao SM, Hays AR, Walter R, Chen JS, Snigirevskaya ES, Raikhel AS: Mosquito cathepsin B-like protease involved in embryonic degradation of vitellin is produced as a latent extraovarian precursor. Journal of Biological Chemistry 1999, 274(19):|33||-|332|. 
76. Sokal RR, Rohlf F): Biometry: The Principles and Practice Of Statistics In Biological Research. 3rd edition. New York: Freeman; 1995.

77. Edwards MJ, Severson DW, Hagedorn HH: Vitelline envelope genes of the yellow fever mosquito, Aedes aegypti. Insect Biochemistry and Molecular Biology 1998, 28( ( 2):915-925.

78. Han YS, Barillas-Mury C: Implications of Time Bomb model of ookinete invasion of midgut cells. Insect Biochemistry and Molecular Biology 2002, 32(10): |3||-1316.

79. Shen ZC, Dimopoulos G, Kafatos FC, Jacobs-Lorena M: A cell surface mucin specifically expressed in the midgut of the malaria mosquito Anopheles gambiae. Proceedings of the National Academy of Sciences of the United States of America 1999, 96(10):5610-5615.

80. Carraway KL, Ramsauer VP, Haq B, Carrothers Carraway CA: Cell signaling through membrane mucins. Bioessays 2003, 25(I):66-7I.

8I. Morishima N: Control of cell fate by Hsp70: More than an evanescent meeting. Journal of Biochemistry 2005, I37(4):449-453.

82. Shen ZC, Jacobs-Lorena M: A type I peritrophic matrix protein from the malaria vector Anopheles gambiae binds to chitin Cloning, expression, and characterization. Journal of Biological Chemistry | 998, 273(28): |7665-17670.

83. Langer RC, Li FW, Popov V, Kurosky A, Vinetz JM: Monoclonal antibody against the Plasmodium falciparum chitinase, PfCHTI, recognizes a malaria transmission-blocking epitope in Plasmodium gallinaceum ookinetes unrelated to the chitinase PgCHTI. Infection and Immunity 2002, 70(3): $1581-1590$.

84. Langer RC, Vinetz JM: Plasmodium ookinete-secreted chitinase and parasite penetration of the mosquito peritrophic matrix. Trends In Parasitology 200I, 17(6):269-272.

85. Tsuboi T, Kaneko O, Eitoku C, Suwanabun N, Sattabongkot J, Vinetz JM, Torii M: Gene structure and ookinete expression of the chitinase genes of Plasmodium vivax and Plasmodium yoelii. Molecular and Biochemical Parasitology 2003, I 30(I):5I-54.

86. Li FW, Templeton TJ, Popov V, Comer JE, Tsuboi T, Torii M, Vinetz JM: Plasmodium ookinete -secreted proteins secreted through a common micronemal pathway are targets of blocking malaria transmission. Journal of Biological Chemistry 2004, 279(25):26635-26644.

87. Muller HM, Catteruccia F, Vizioli J, DellaTorre A, Crisanti A: Constitutive and blood meal-induced trypsin genes in Anopheles gambiae. Experimental Parasitology 1995, 8I(3):37I-385.

88. Muller HM, Crampton JM, Dellatorre A, Sinden R, Crisanti A: Members Of A Trypsin Gene Family in Anopheles gambiae are Induced in the Gut by Blood Meal. Embo Journal 1993, | 2(7):289|-2900.

89. Vizioli J, Catteruccia F, della Torre A, Reckmann I, Muller HM: Blood digestion in the malaria mosquito Anopheles gambiae Molecular cloning and biochemical characterization of two inducible chymotrypsins. European Journal of Biochemistry 200I, 268( I 4):4027-4035

90. Lemos FJA, Cornel AJ, JacobsLorena M: Trypsin and aminopeptidase gene expression is affected by age and food composition in Anopheles gambiae. Insect Biochemistry and Molecular Biology 1996, 26(7):65I-658.

91. Gwadz R, Collins FH: Anopheline mosquitoes and the agents they transmit. In The Biology of Disease Vectors Edited by: Beaty BJ Marquardt WC. Niwot CO: University Press of Colorado; 1996:73-83.

92. Sinden RE: Infection of mosquitoes with rodent malaria. In Molecular Biology of Insect Disease Vectors: A methods manual Edited by: Crampton JM, Beard CB, Louis C. New York: Chapman and Hall; | 997:67-9|.

93. Vernick KD, Fujioka H, Seeley DC, Tandler B, Aikawa M, Miller LH: Plasmodium gallinaceum - A Refractory Mechanism of Ookinete Killing in the Mosquito, Anopheles gambiae. Experimental Parasitology 1995, 80(4):583-595.

94. Rohlf F], Sokal RR: Statistical Tables. New York: Freeman; 1995.

95. BLAST [http://www.ncbi.nlm.nih.gov/BLAST/]

96. Altschul SF, Madden TL, Schaffer AA, Zhang JH, Zhang Z, Miller W Lipman DJ: Gapped BLAST and PSI-BLAST: a new generation of protein database search programs. Nucleic Acids Research 1997, 25(I7):3389-3402.
97. The Institute for Genomic Research (TIGR) [http:// www.tigr.org/tdb/ttgi/]

98. BDGP: GadFly: Genome Annotation Database of Drosophila [http://www.fruitfly.org/annot/]

99. Quackenbush J, Cho J, Lee D, Liang F, Holt I, Karamycheva S, Parvizi B, Pertea G, Sultana R, White J: The TIGR Gene Indices: analysis of gene transcript sequences in highly sampled eukaryotic species. Nucleic Acids Research 200I, 29(I): 159-164.

100. Quackenbush J, Liang F, Holt I, Pertea G, Upton J: The TIGR Gene Indices: reconstruction and representation of expressed gene sequences. Nucleic Acids Research 2000, 28(I): |4I-I45.

I0I. KEGG: Kyoto Encyclopedia of Genes and Genomes [http:// www.genome.ad.jp/kegg]

102. The Gene Ontology Consortium [http://www.geneontol ogy.org/]

103. Ashburner M, Ball CA, Blake JA, Botstein D, Butler H, Cherry JM, Davis AP, Dolinski K, Dwight SS, Eppig JT, Harris MA, Hill DP, IsselTarver L, Kasarskis A, Lewis S, Matese JC, Richardson JE, Ringwald M, Rubin GM, Sherlock G: Gene Ontology: tool for the unification of biology. Nature Genetics 2000, 25(I):25-29.

104. Romualdi C, Bortoluzzi S, D'Alessi F, Danieli GA: IDEG6: a web tool for detection of differentially expressed genes in multiple tag sampling experiments. Physiological Genomics 2003, I 2(2): $159-162$

105. Richman AM, Bulet P, Hetru C, BarillasMury C, Hoffmann JA, Kafatos FC: Inducible immune factors of the vector mosquito Anopheles gambiae : Biochemical purification of a defensin antibacterial peptide and molecular cloning of preprodefensin cDNA. Insect Molecular Biology 1996, 5(3):203-210.

106. Salazar CE, Mills-Hamm D, Kumar V, Collins FH: Sequence of a cDNA from the Mosquito Anopheles gambiae Encoding a Homolog of Human Ribosomal Protein-S7. Nucleic Acids Research 1993, 21(17):4|47-4I47.

Publish with Biomed Central and every scientist can read your work free of charge

"BioMed Central will be the most significant development for disseminating the results of biomedical research in our lifetime. "

Sir Paul Nurse, Cancer Research UK

Your research papers will be:

- available free of charge to the entire biomedical community

- peer reviewed and published immediately upon acceptance

- cited in PubMed and archived on PubMed Central

- yours - you keep the copyright
BioMedcentral 